\title{
Implications for working time policies
}

Link to publication record in Manchester Research Explorer

\section{Citation for published version (APA):}

Anxo, D., Fagan, C., McCann, D., Lee, S., \& Messenger, J. (2004). Implications for working time policies. In Finding the balance: working time and workers' needs and preferences in industrialized countries (pp. 108-146). Routledge.

\section{Published in:}

Finding the balance: working time and workers' needs and preferences in industrialized countries

\section{Citing this paper}

Please note that where the full-text provided on Manchester Research Explorer is the Author Accepted Manuscript or Proof version this may differ from the final Published version. If citing, it is advised that you check and use the publisher's definitive version.

\section{General rights}

Copyright and moral rights for the publications made accessible in the Research Explorer are retained by the authors and/or other copyright owners and it is a condition of accessing publications that users recognise and abide by the legal requirements associated with these rights.

\section{Takedown policy}

If you believe that this document breaches copyright please refer to the University of Manchester's Takedown Procedures [http://man.ac.uk/04Y6Bo] or contact uml.scholarlycommunications@manchester.ac.uk providing relevant details, so we can investigate your claim.

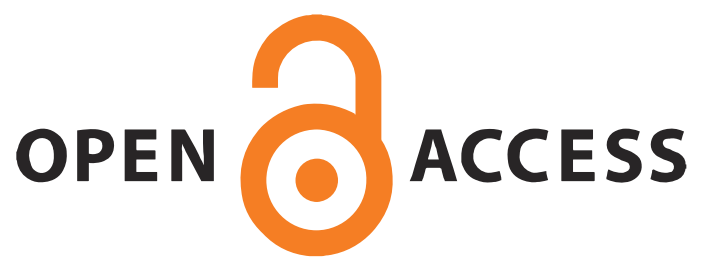



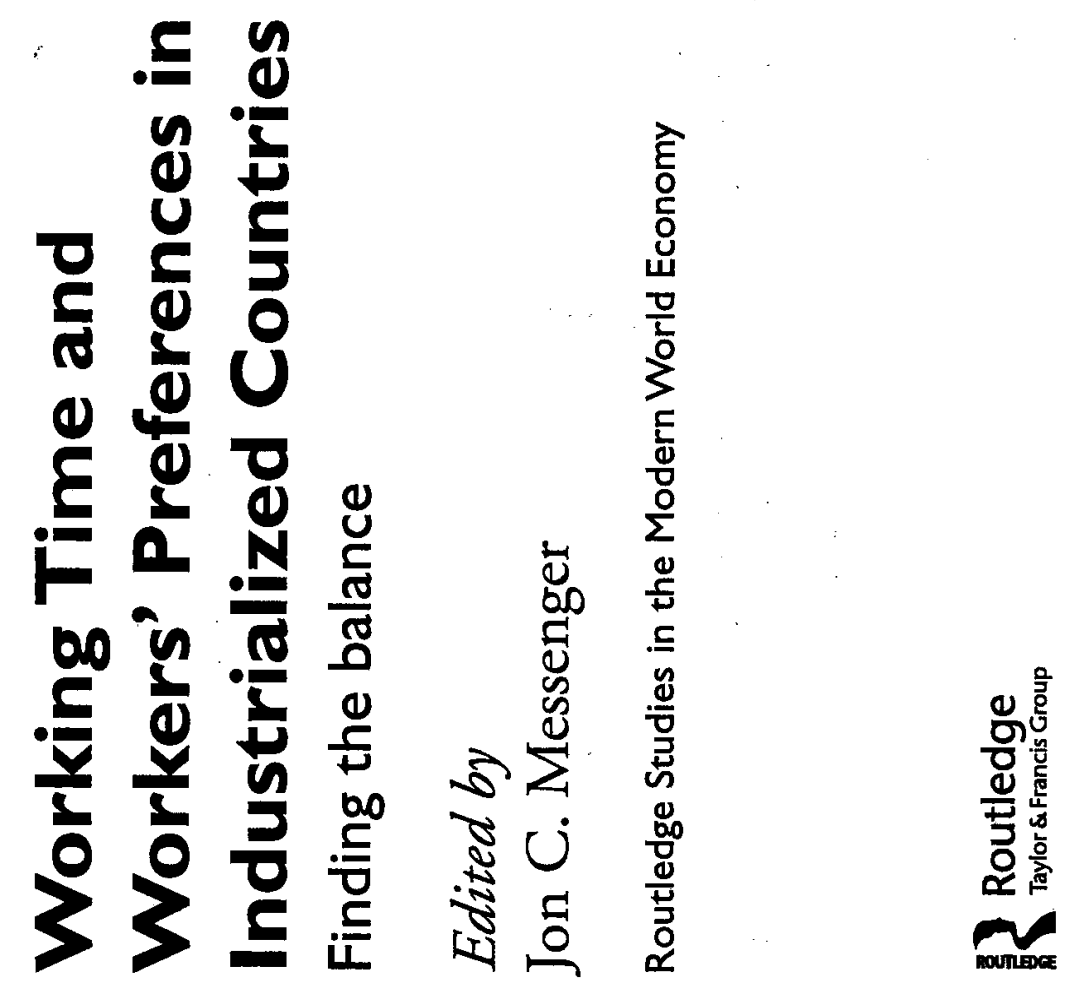


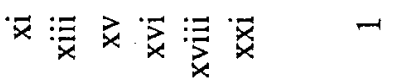
$\therefore \quad$ iิ
8
$\stackrel{\infty}{\stackrel{్}{\prime}}$
栗
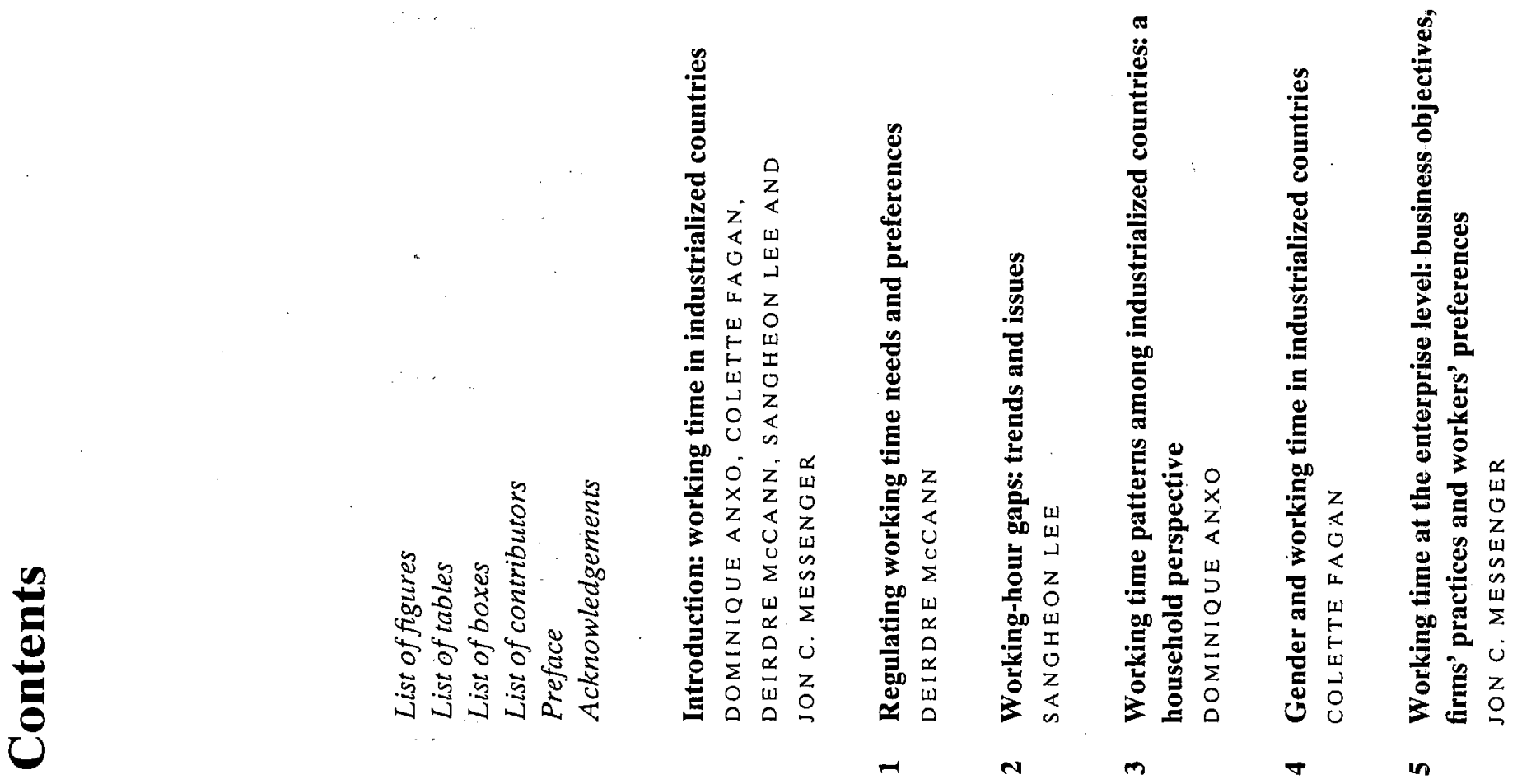

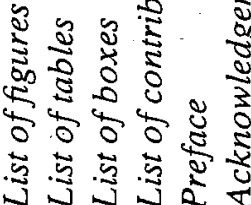

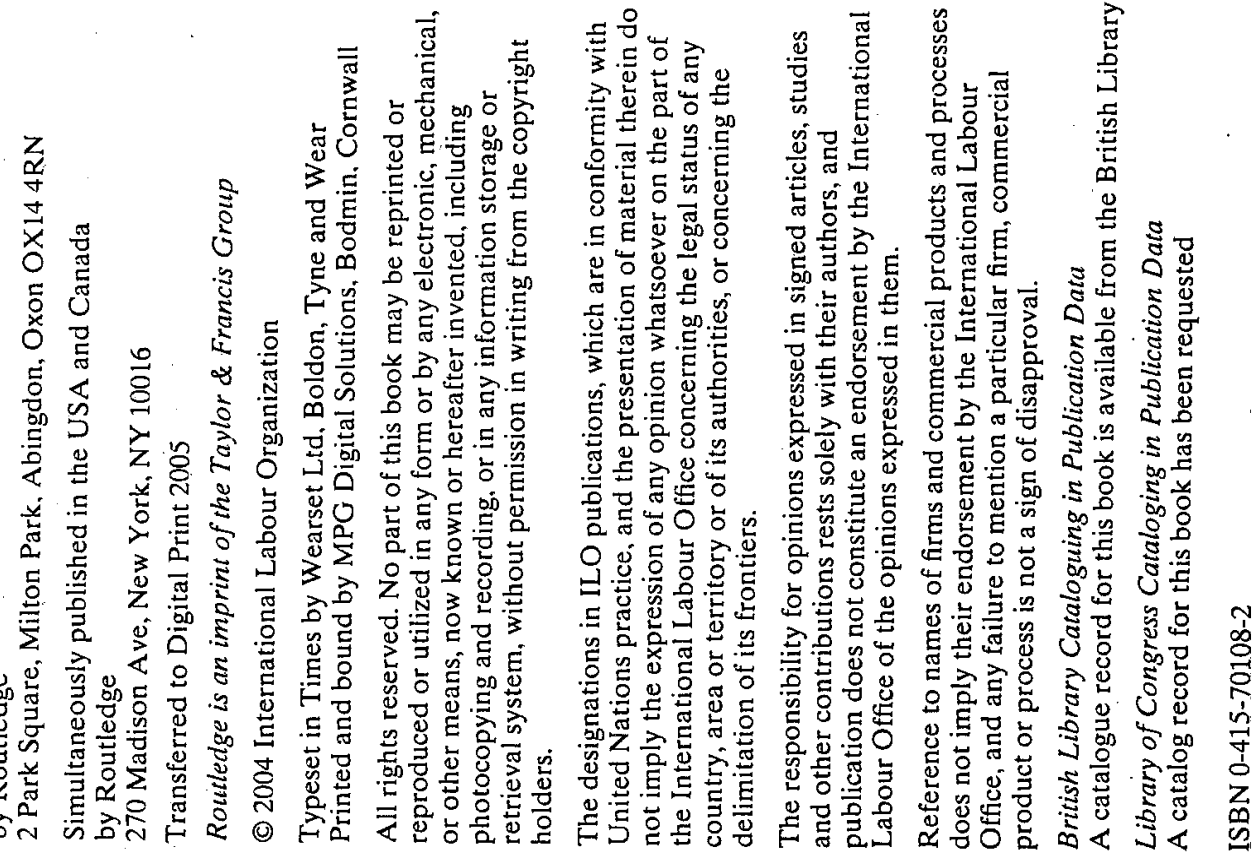


$\stackrel{2}{\approx} \quad \stackrel{\sim}{\sim}$

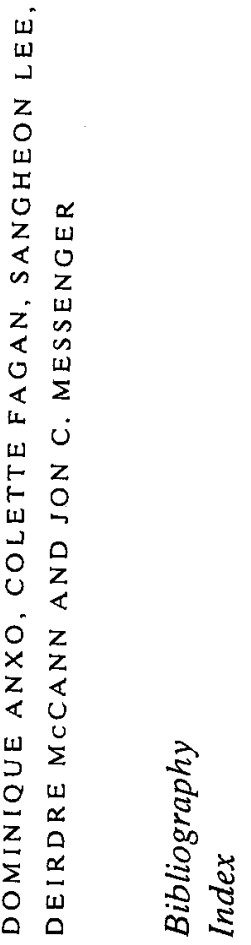




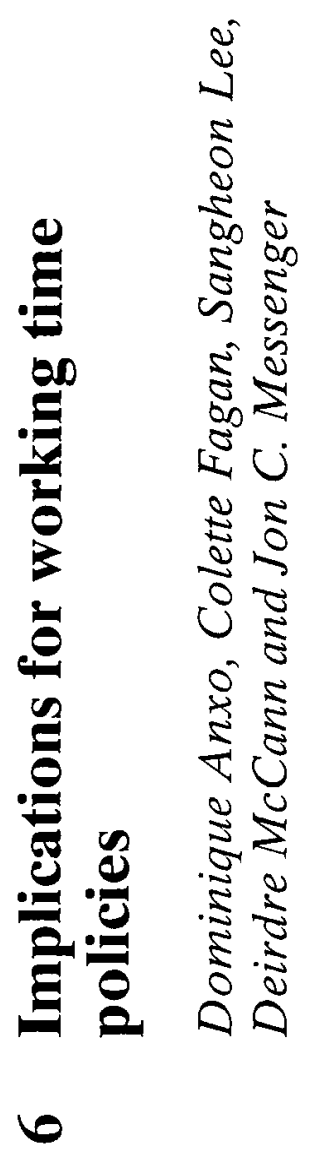

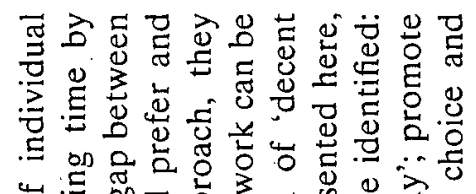

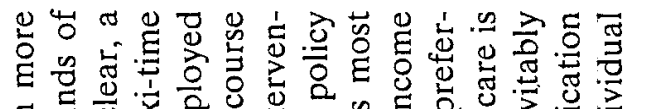

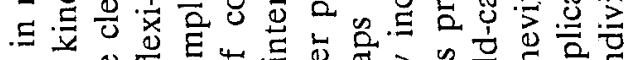
ช o 岁章 on

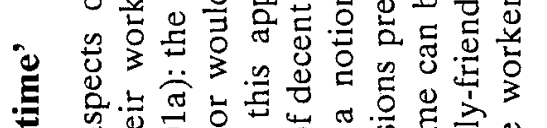

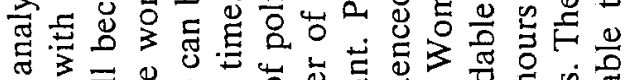

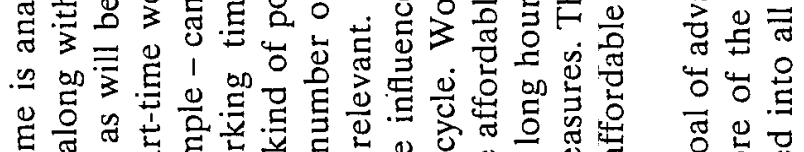

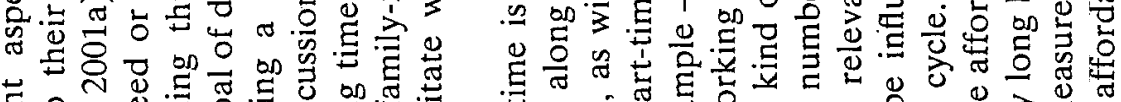

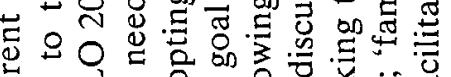

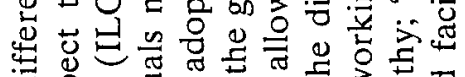

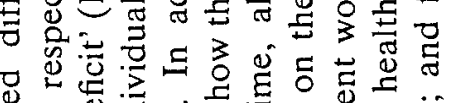

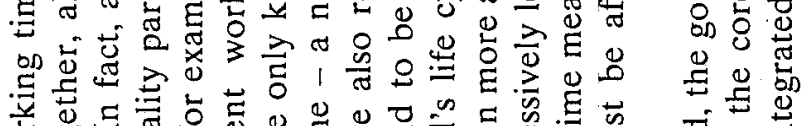

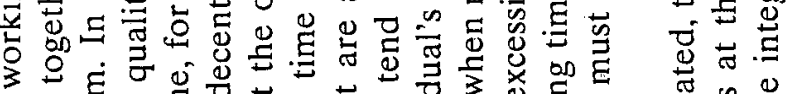
它 1 .

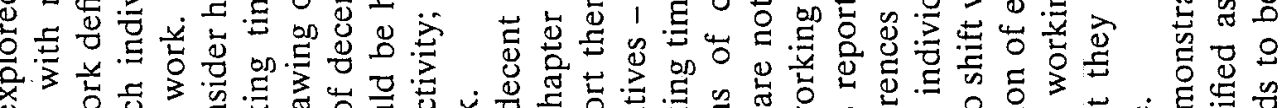

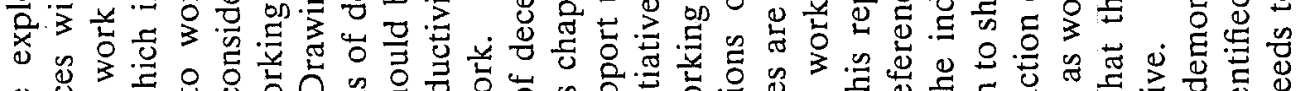

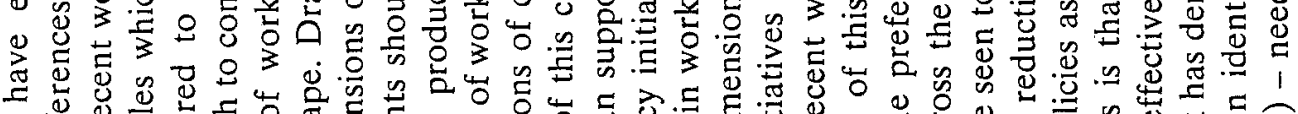

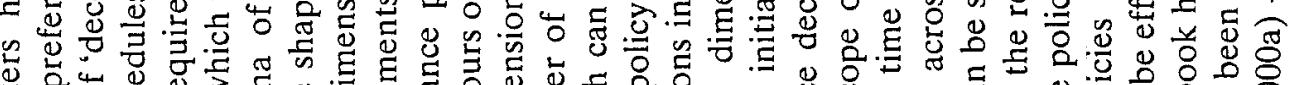

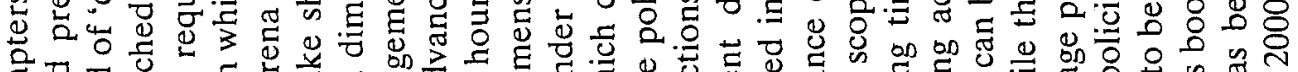

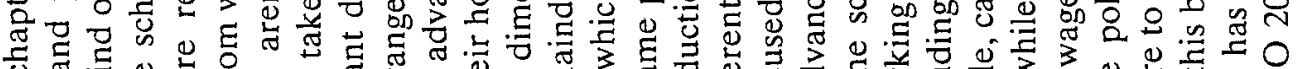

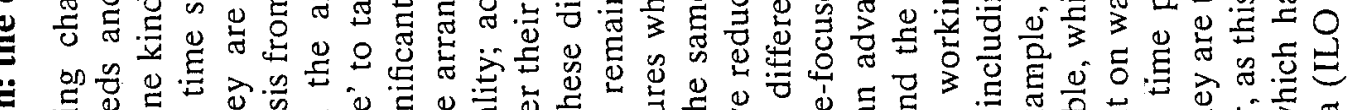

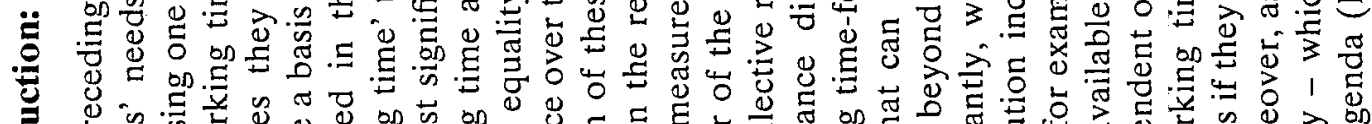

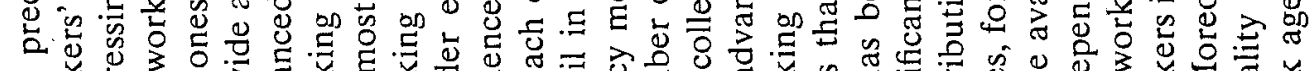

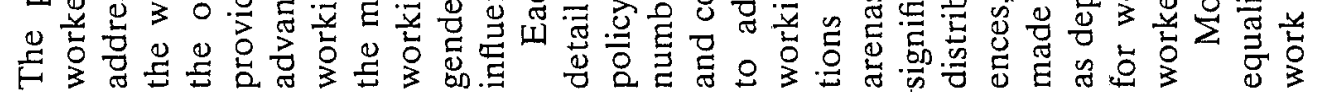




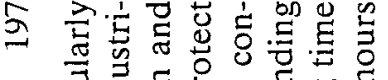

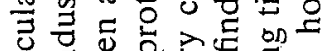

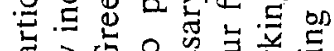

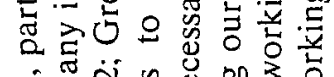
듈

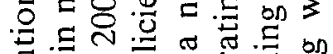

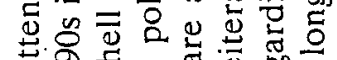

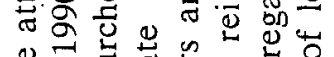

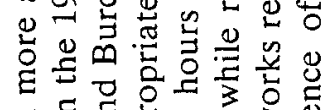
든 5 훙 on 3

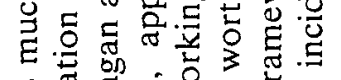

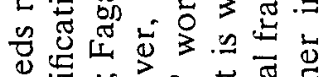
屯

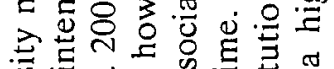

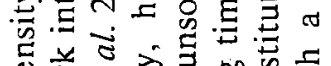

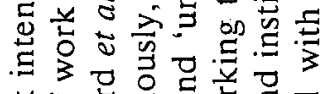

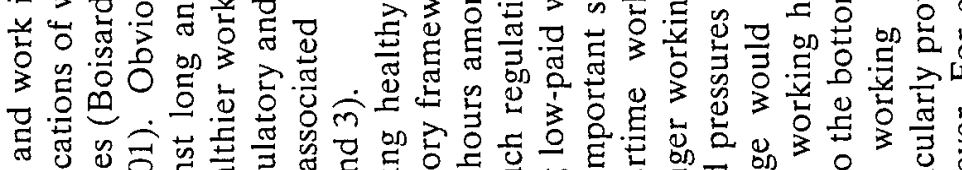

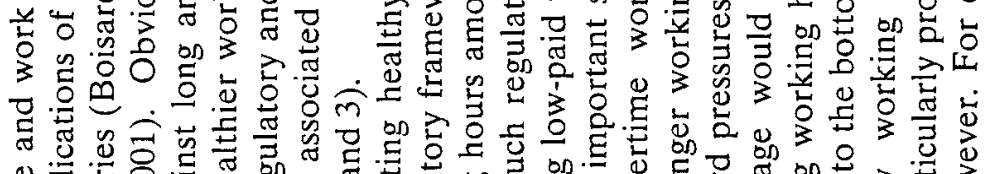

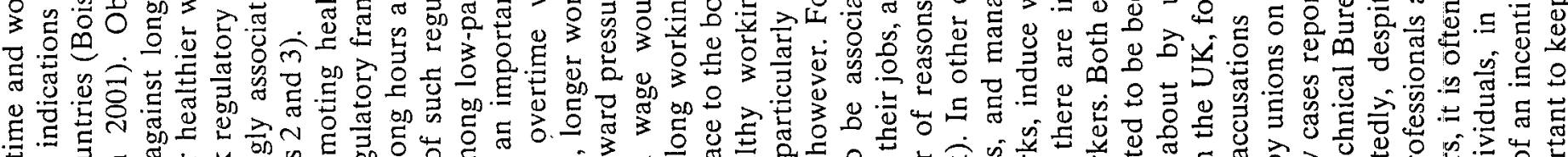

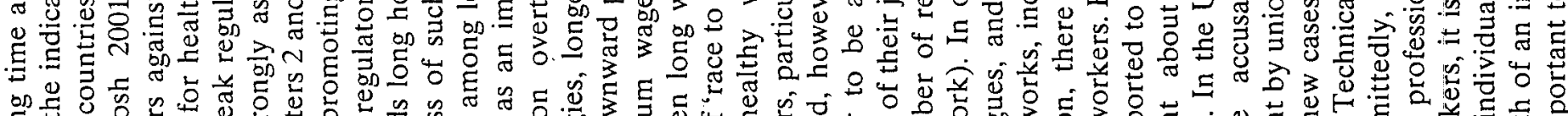

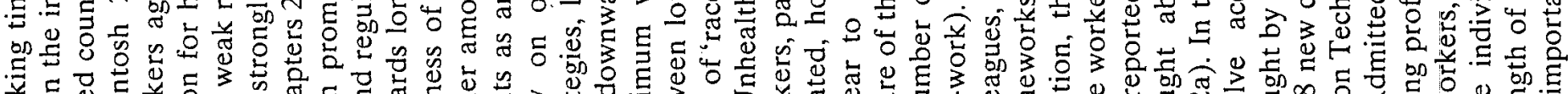

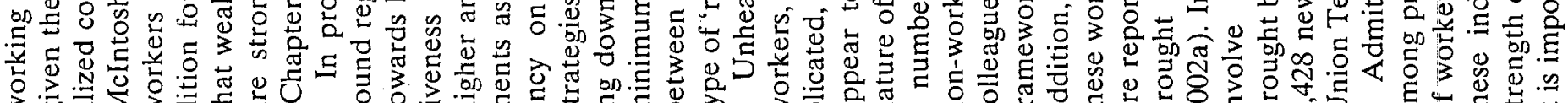

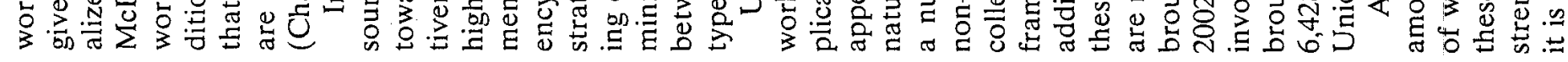

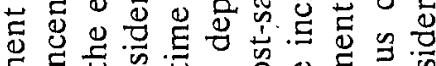

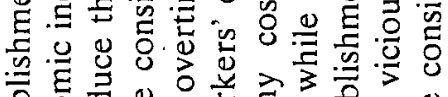

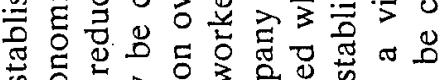

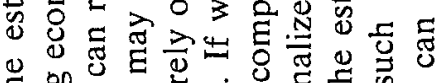

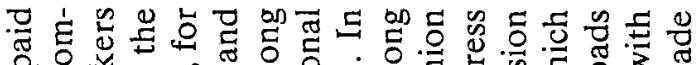
i

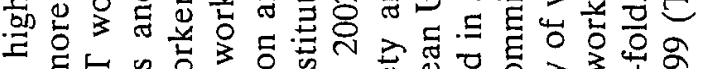

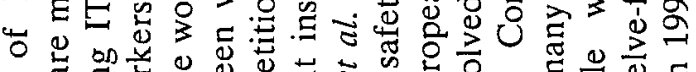

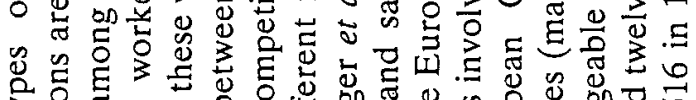

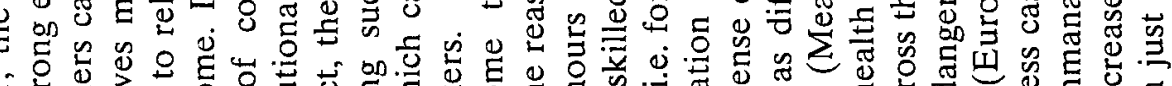

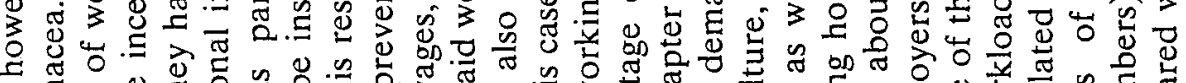

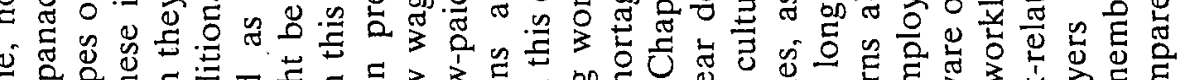

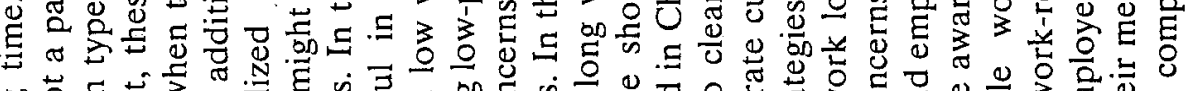

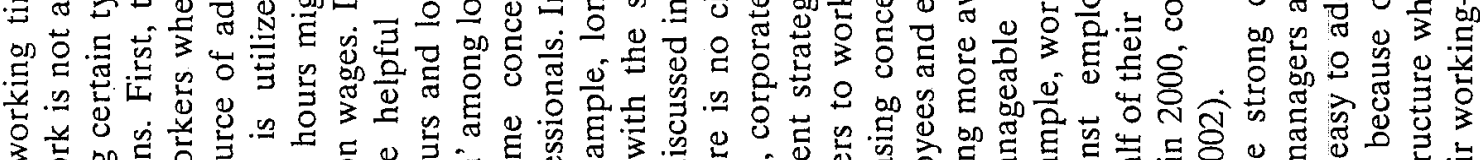

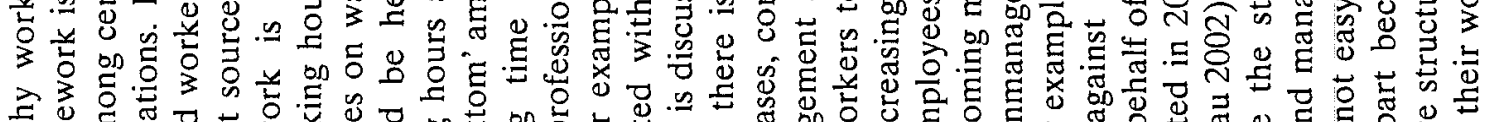

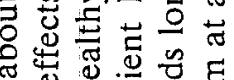

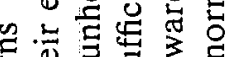

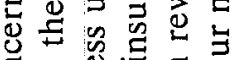

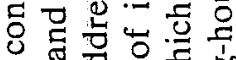
तु० क

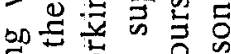

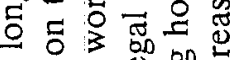
$\exists$ 구워 出过

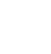
.

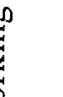

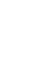

¿ م.

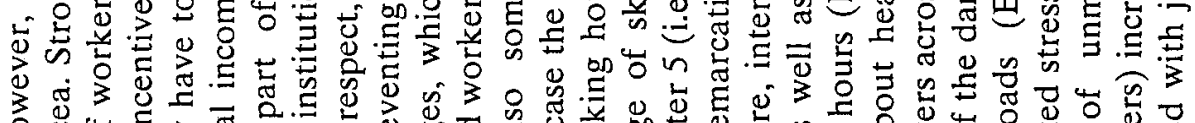

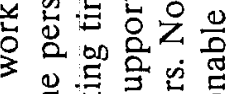

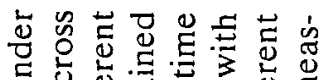

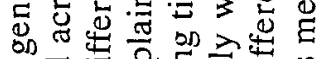

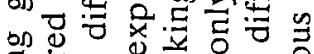
可 0

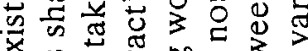

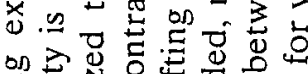

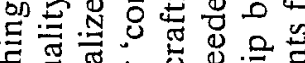

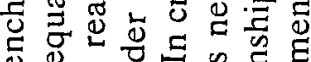

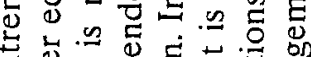

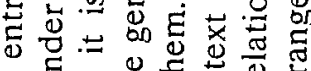

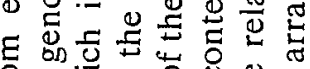

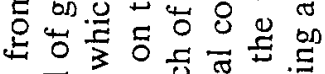
규.

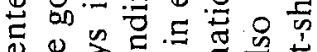

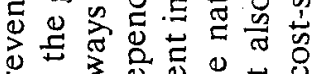
造记

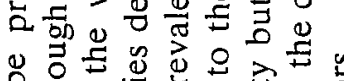

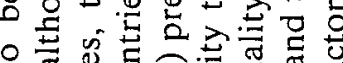

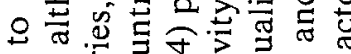


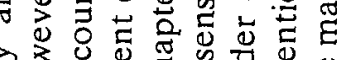

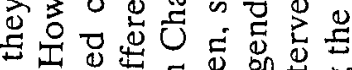

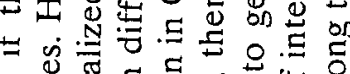

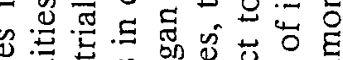

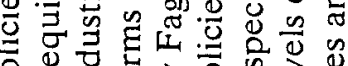

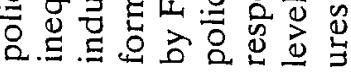


و

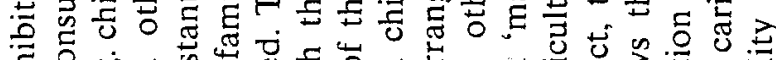

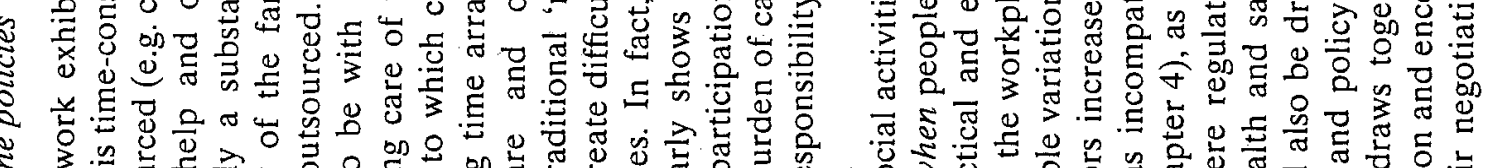

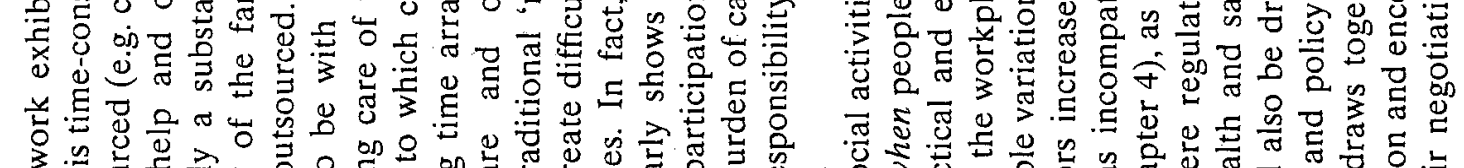

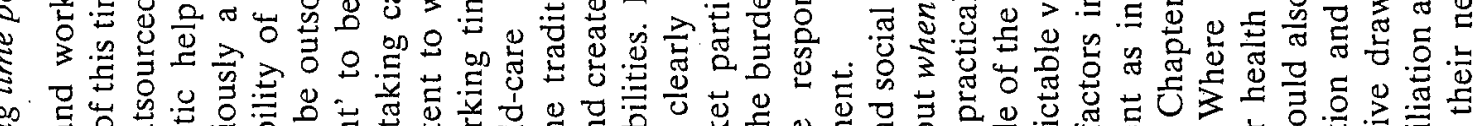

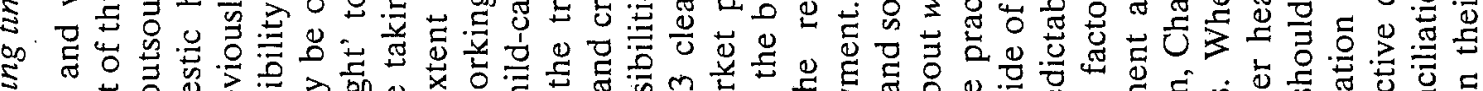

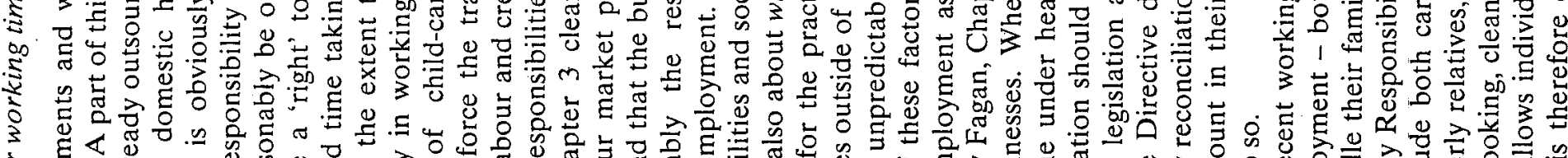

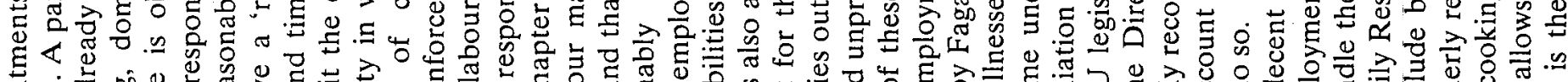

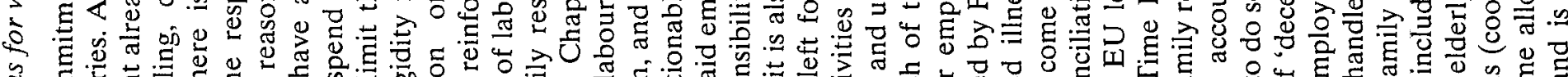
乌 O

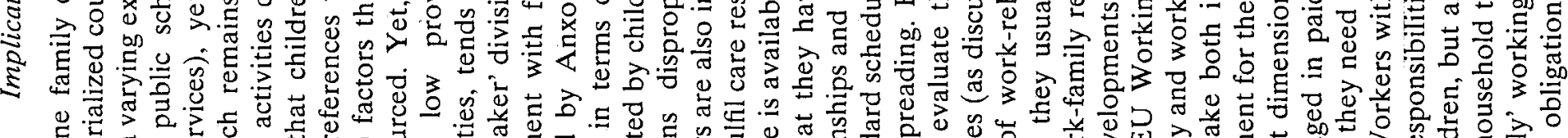

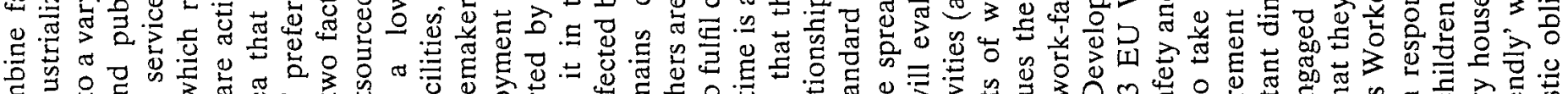

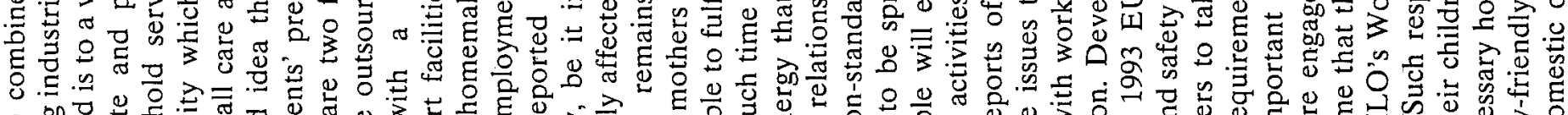

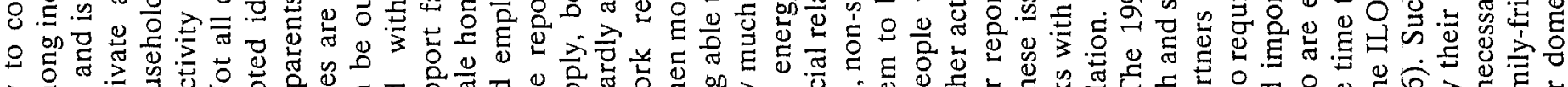

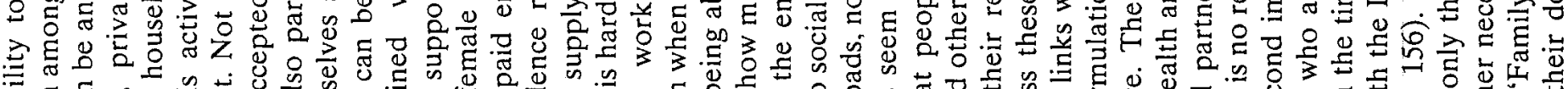

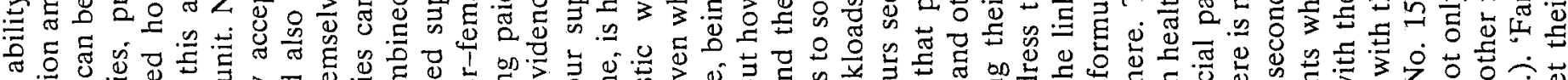

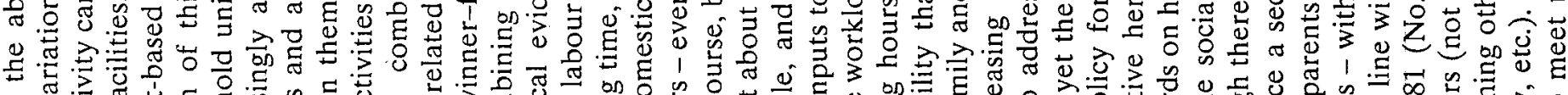

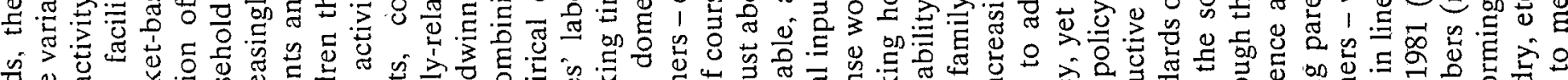

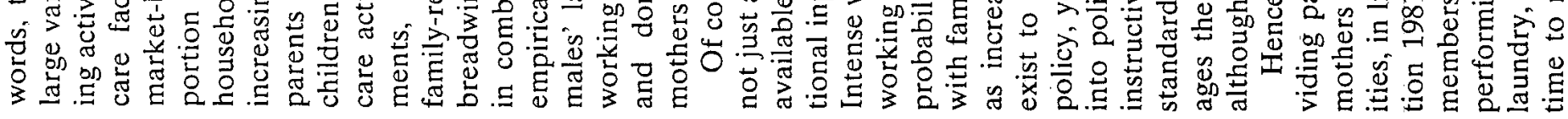

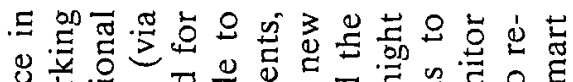

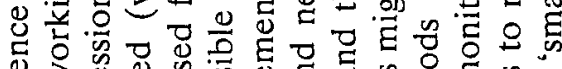

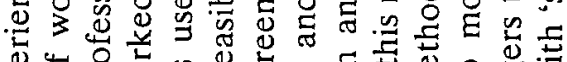

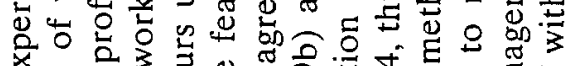

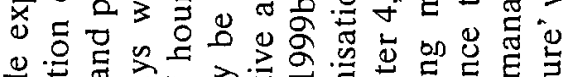

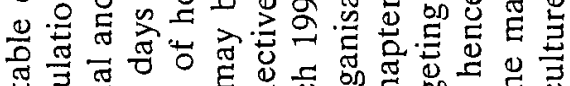

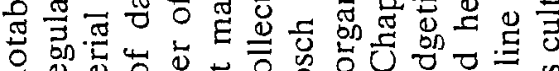

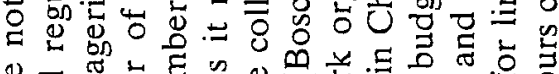

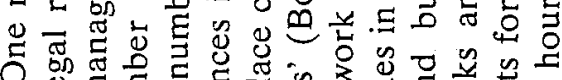

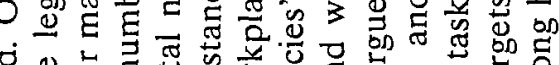

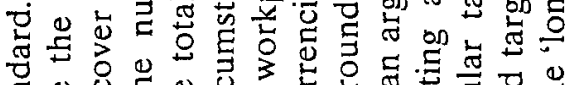

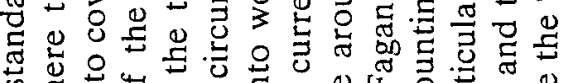
की

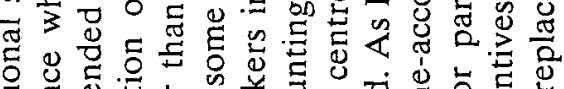

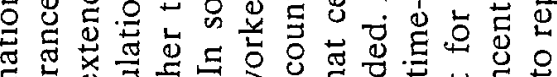

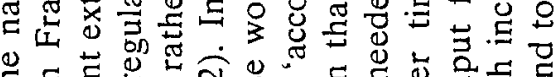

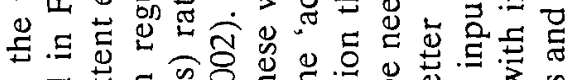

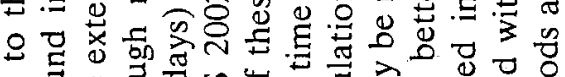

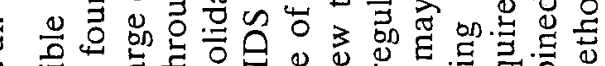

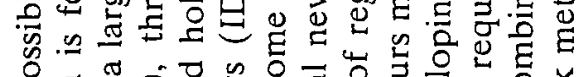

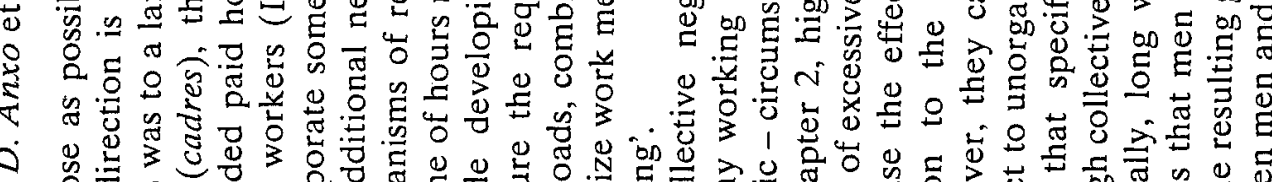

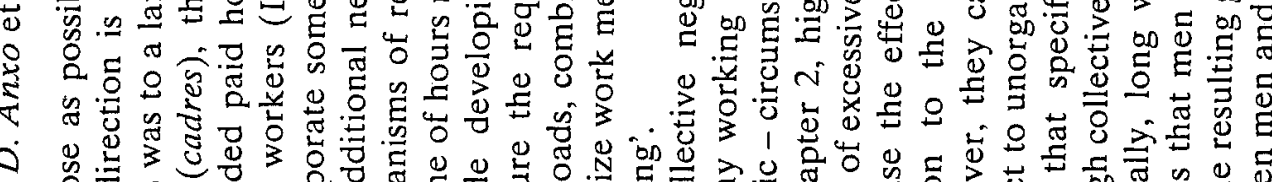

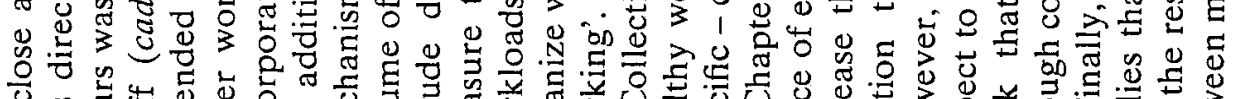

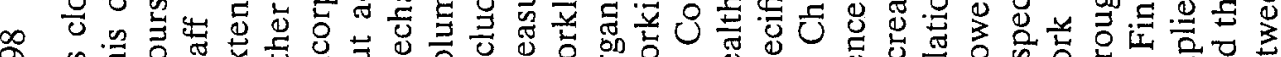

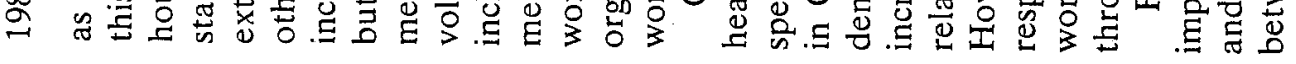

.

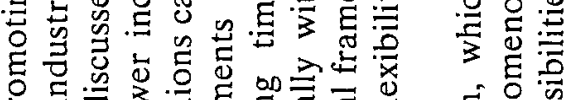

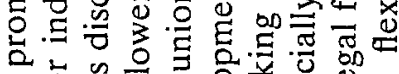
눈

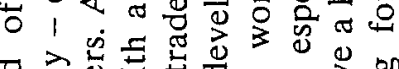

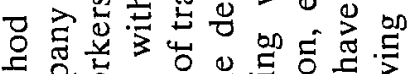

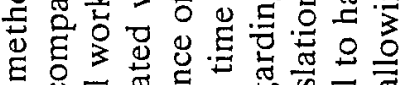

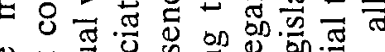

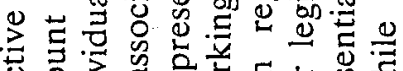

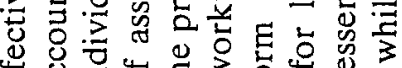

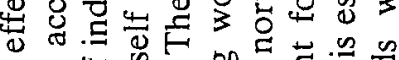

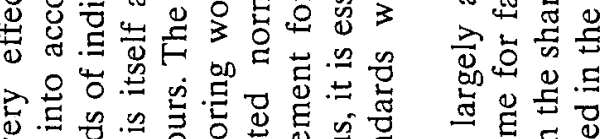

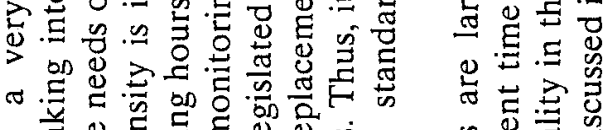

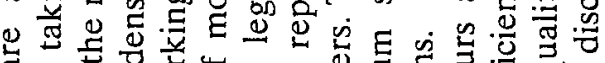

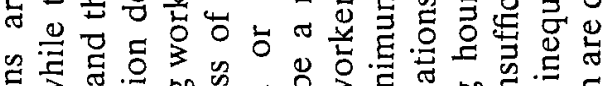

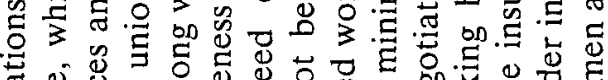

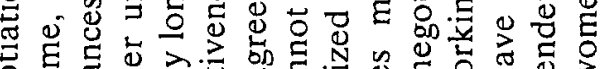

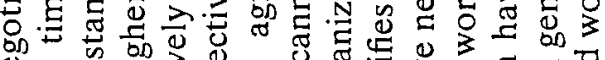

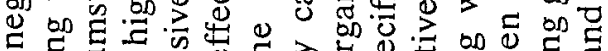

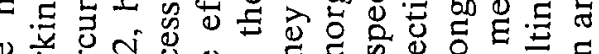
ه

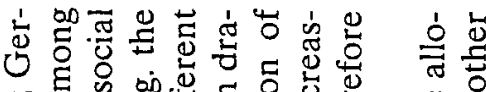

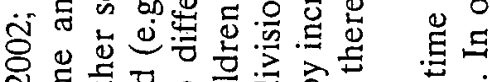

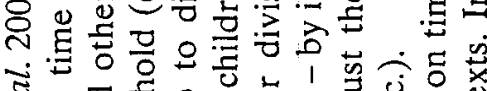

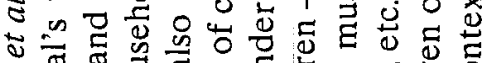
筮

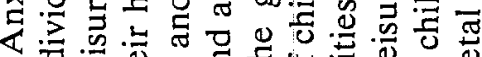
4.

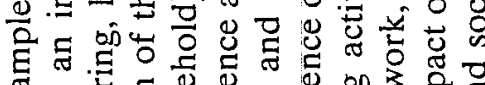

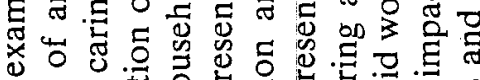

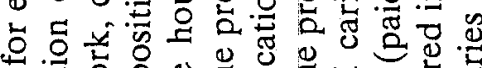
o

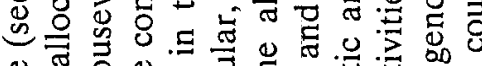
o

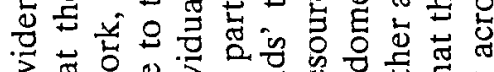

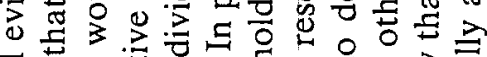

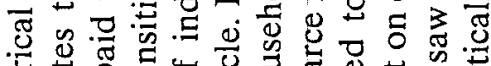

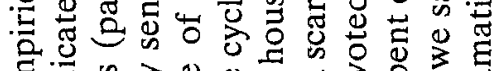

层 E. 造

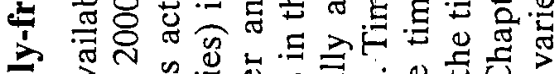
育

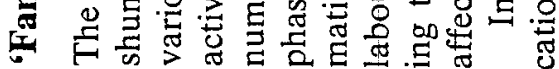




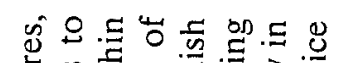

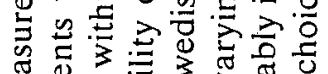
ब

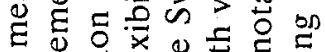

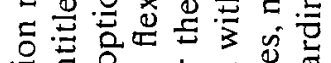

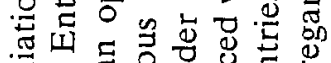
중열 형 \&

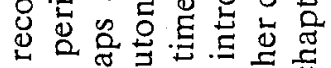

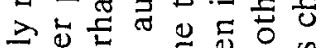

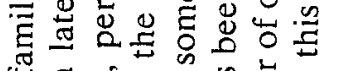

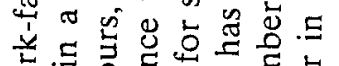

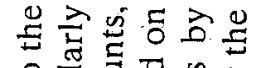

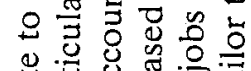

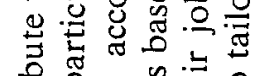

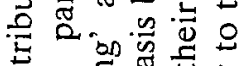

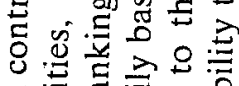

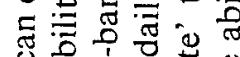

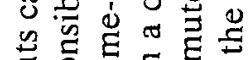

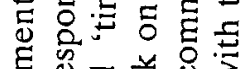

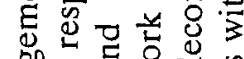

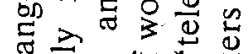

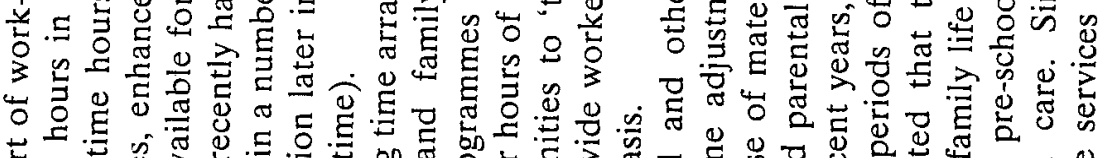

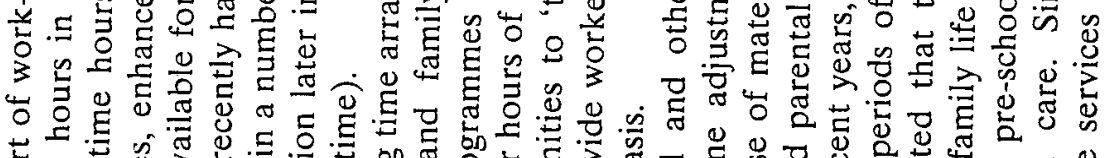

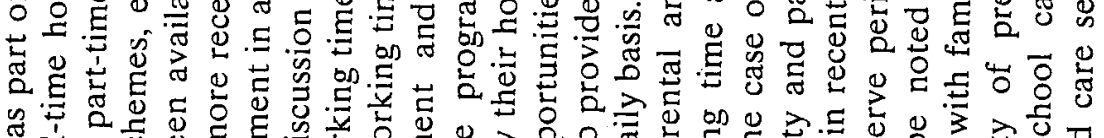

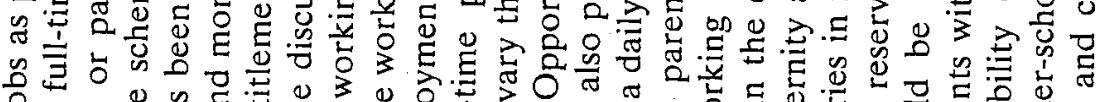

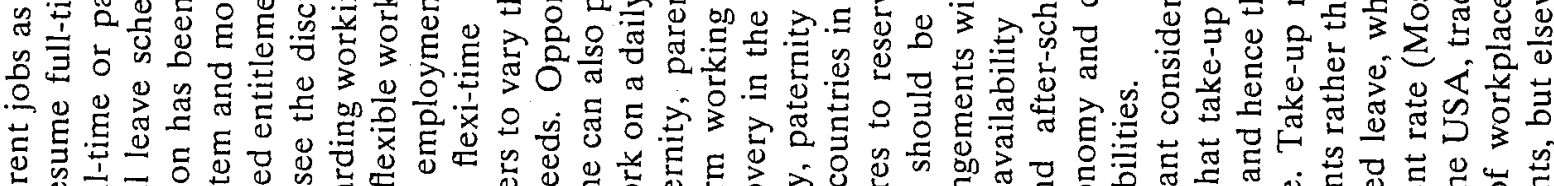

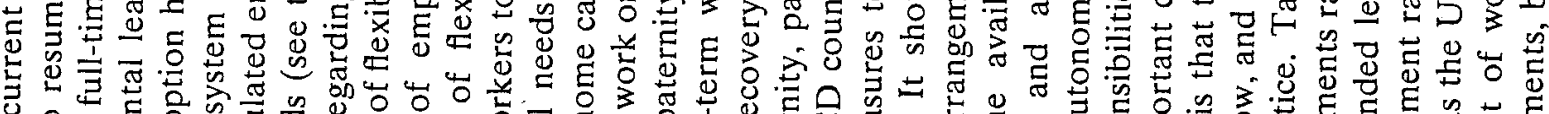

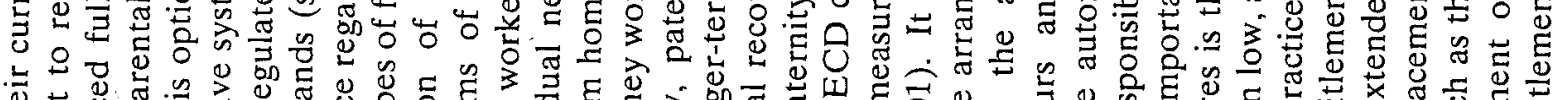

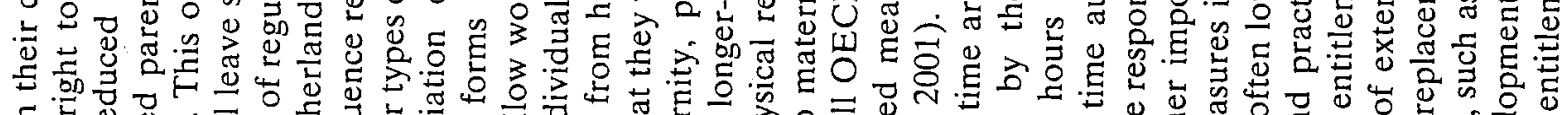
.

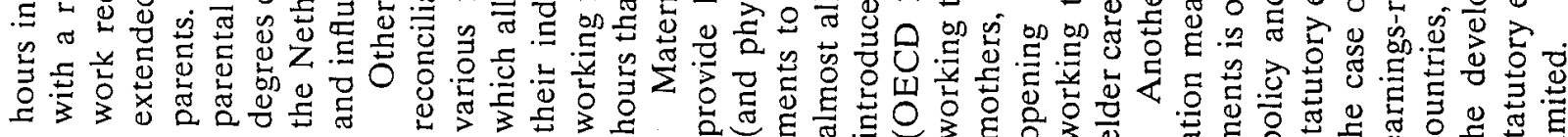

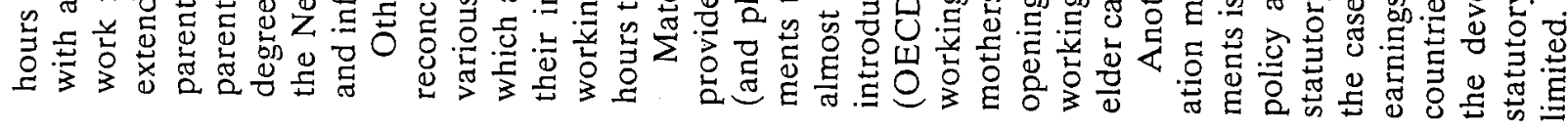

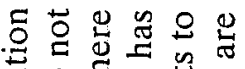

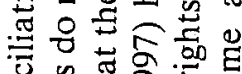
可造 弥

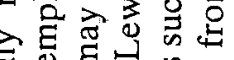
हี I कo 든 3 可焉通占

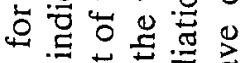

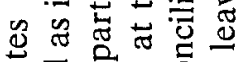

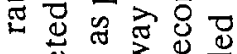
목 i

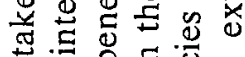
용

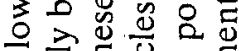
모워

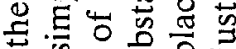
के

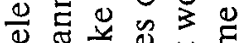
ब 赑 $\varepsilon=$ क

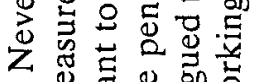

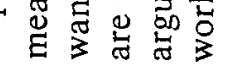

¿

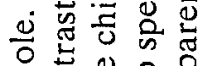

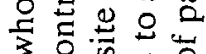
3 응 \&

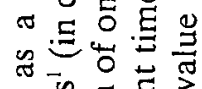

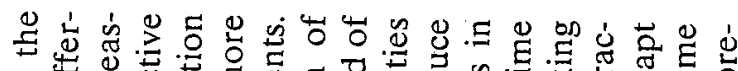

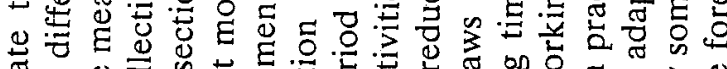

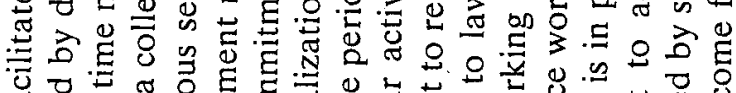

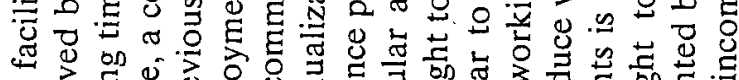

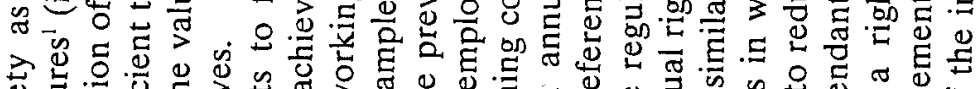

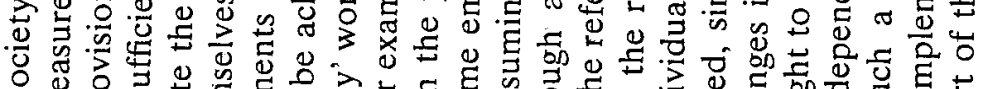

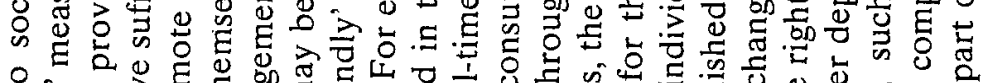

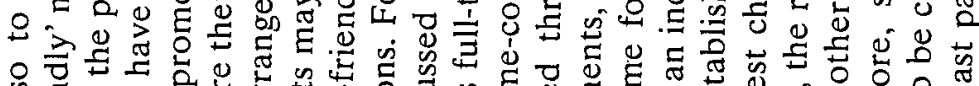
๙

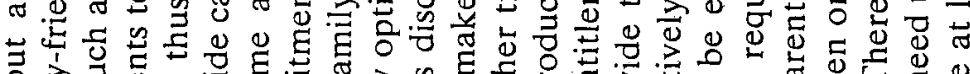

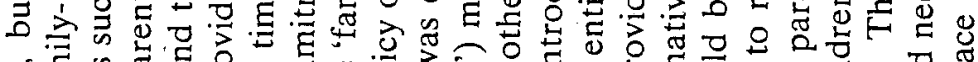

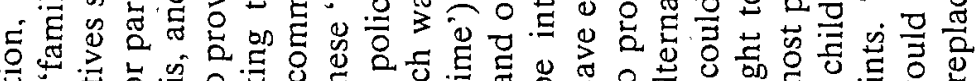

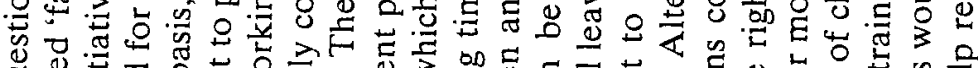

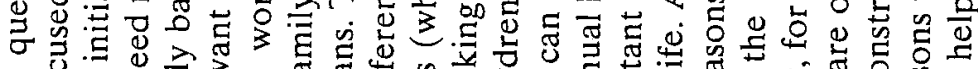

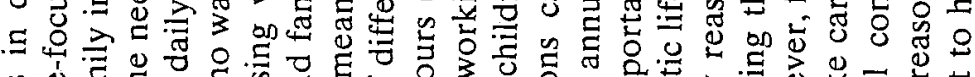

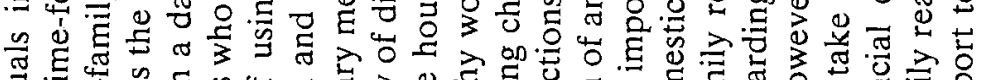

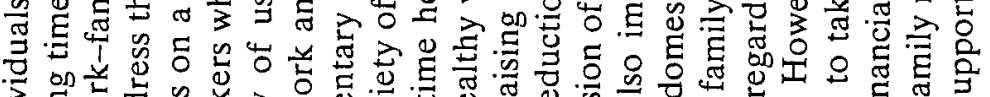

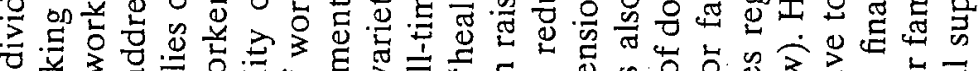

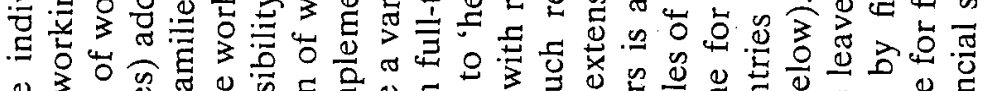
ક

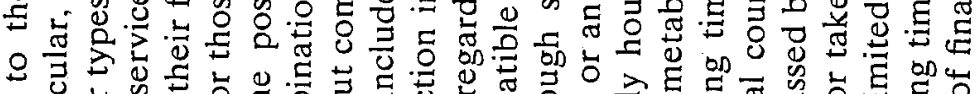

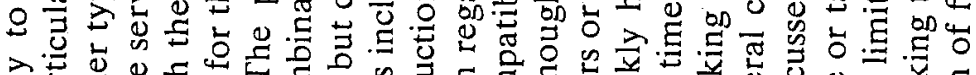

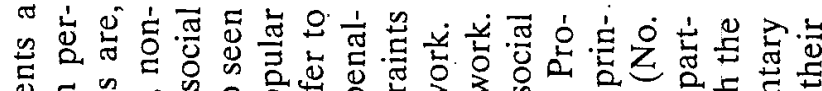

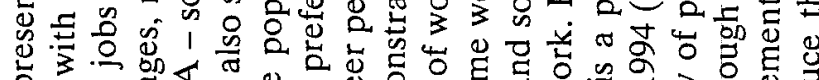

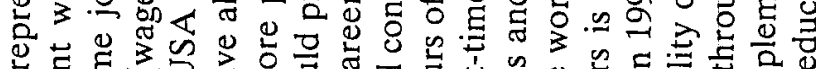

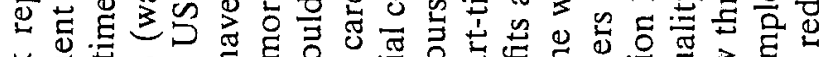

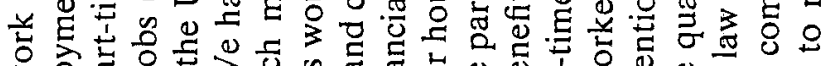

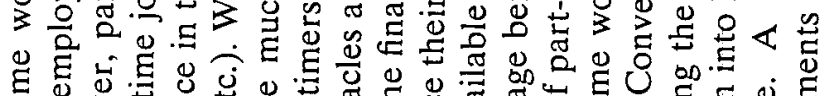

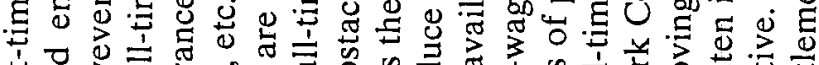

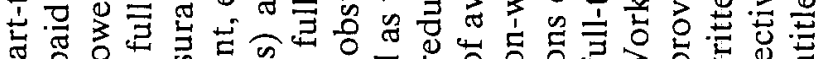

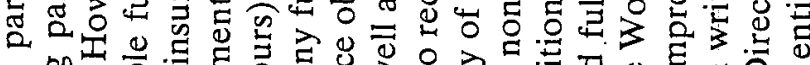

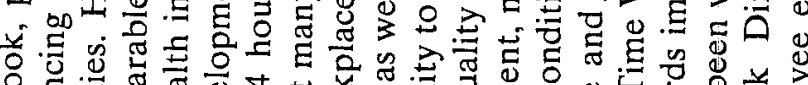

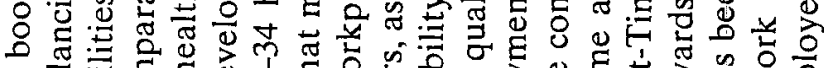

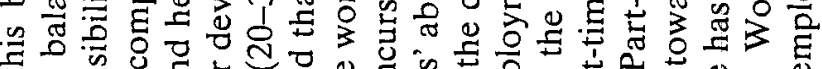

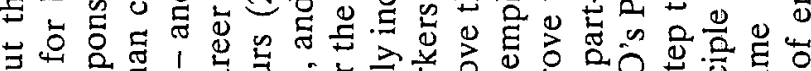

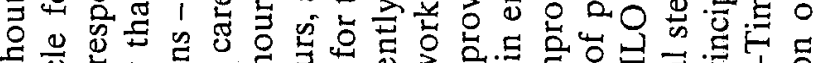
की.

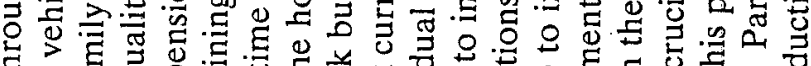

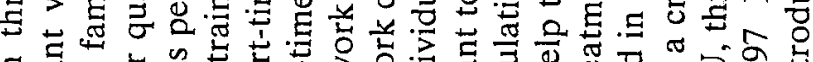

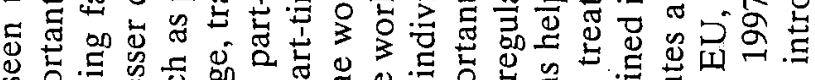
ڤ

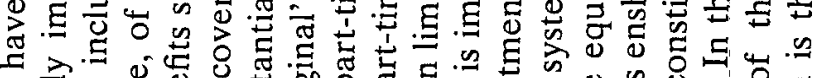

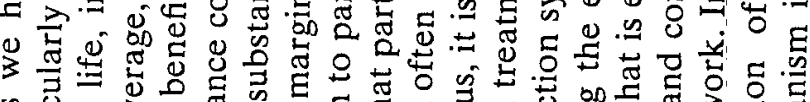

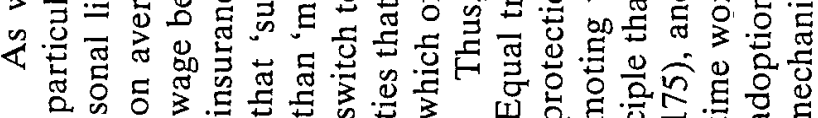




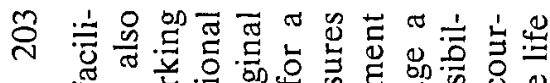
秋

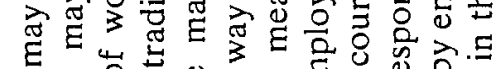
○ E \& 矛 क

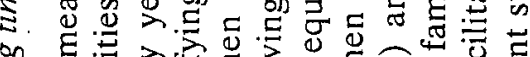

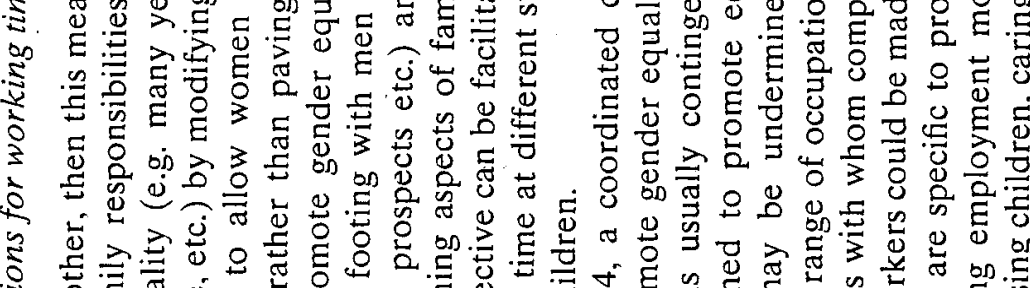

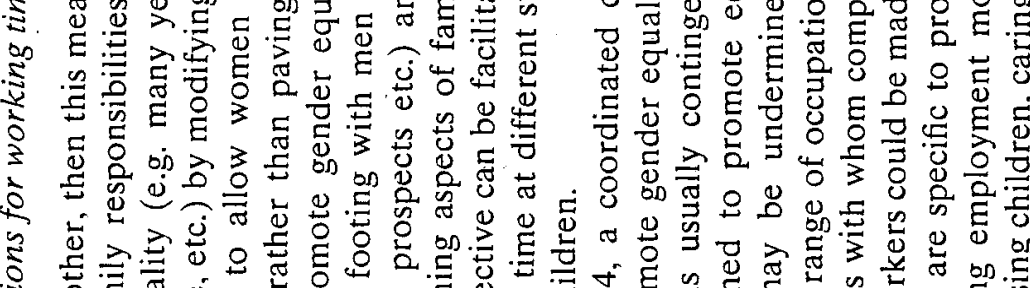

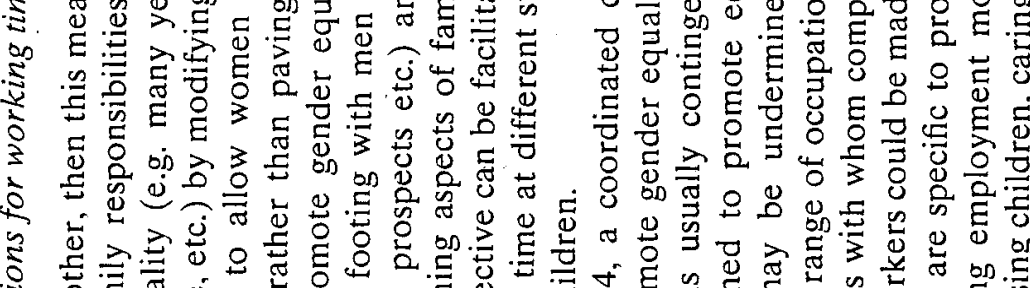

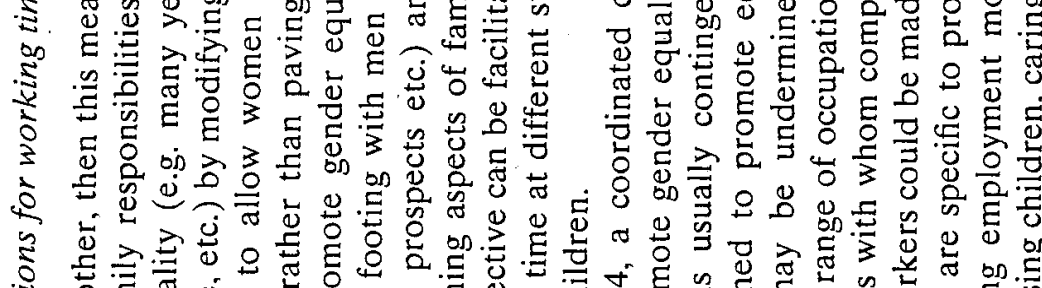

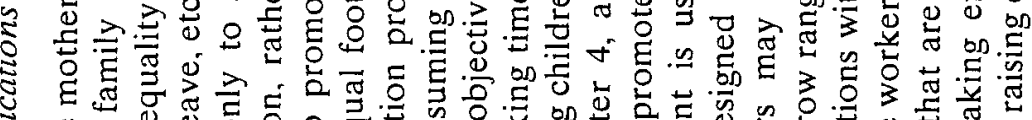

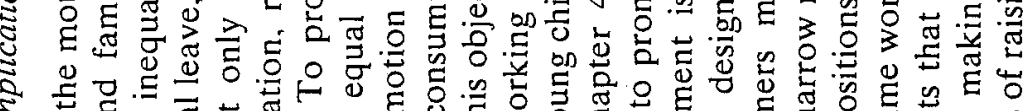
3ㄴ.

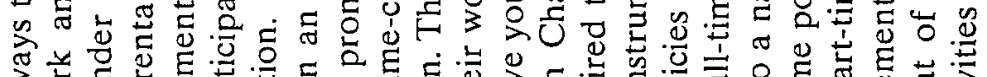

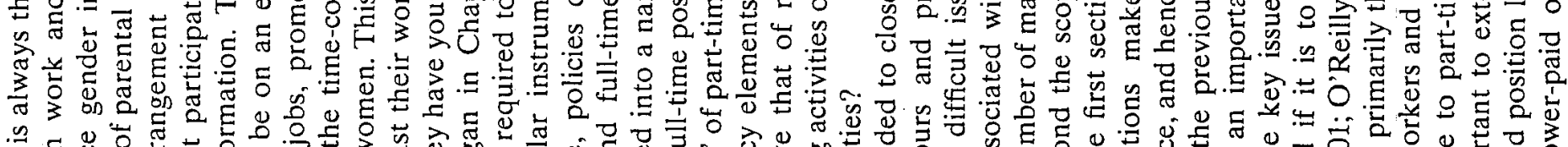

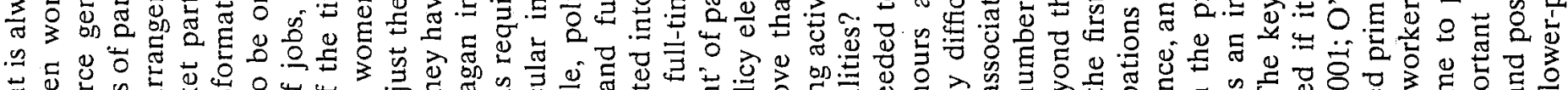

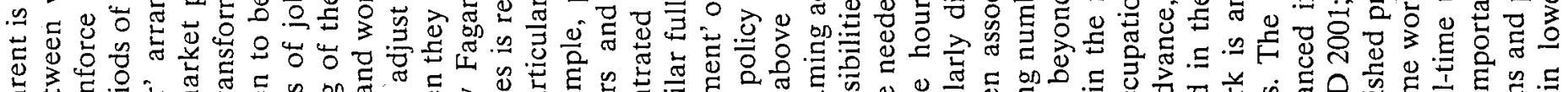

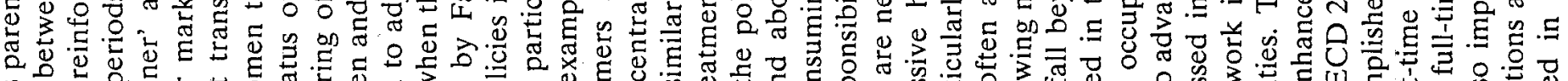
M.

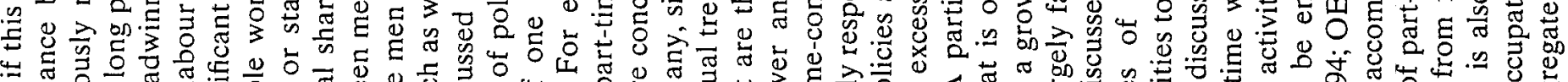

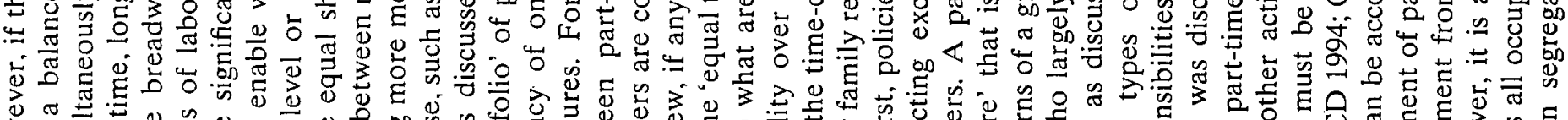

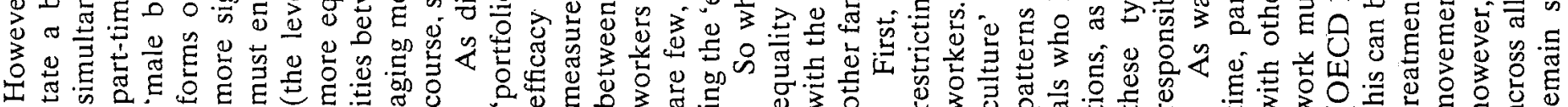

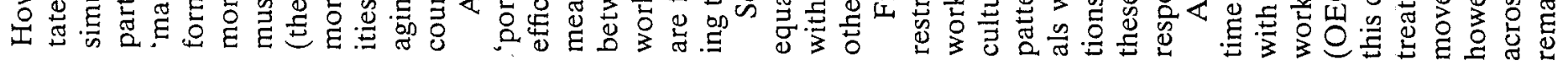

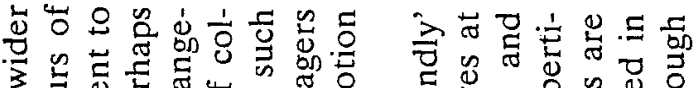

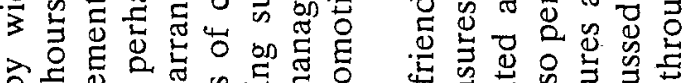

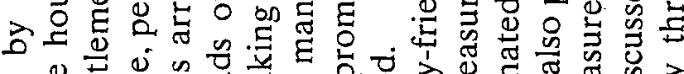

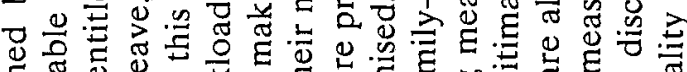

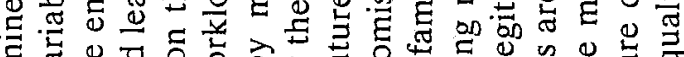

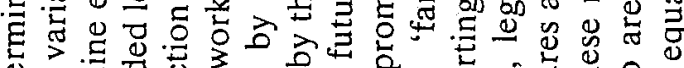

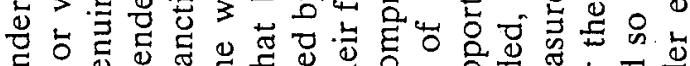

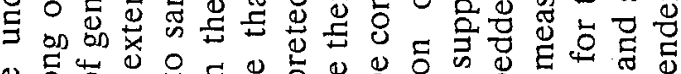
는

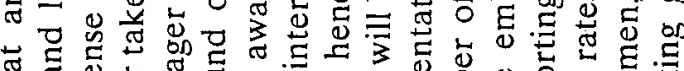

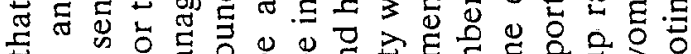

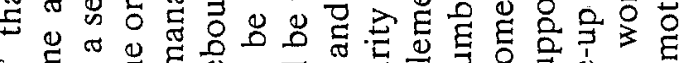

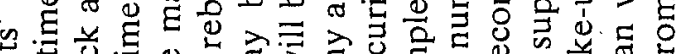

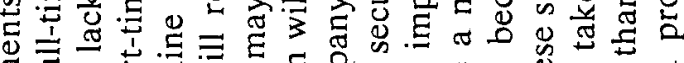

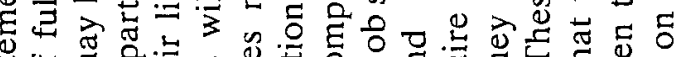

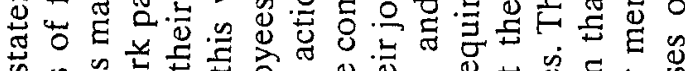

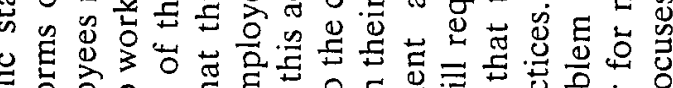

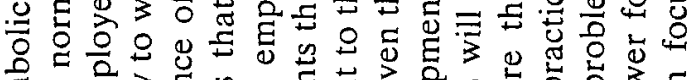

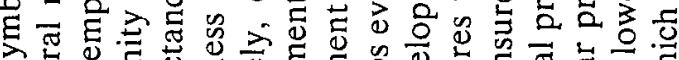

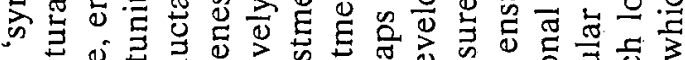
\&

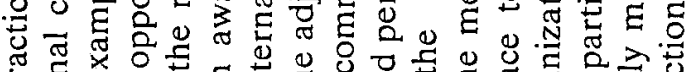

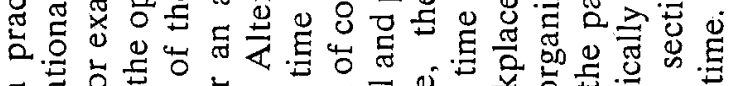
$\Xi$. N

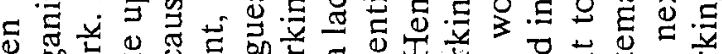

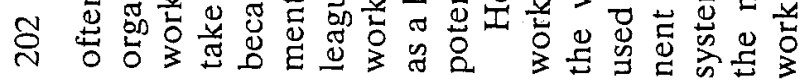

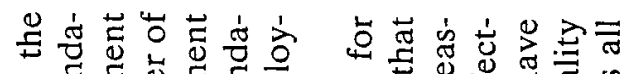

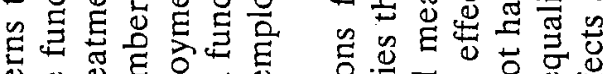

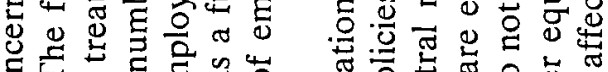

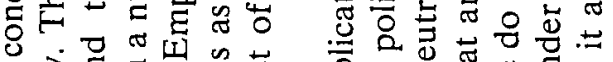

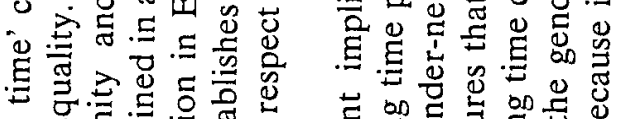

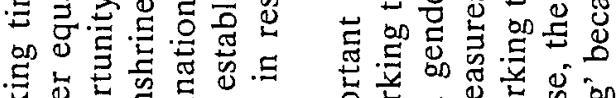

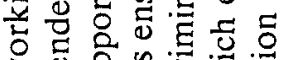

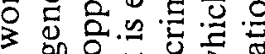

若

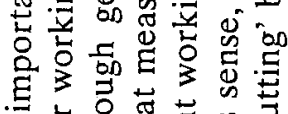

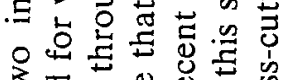

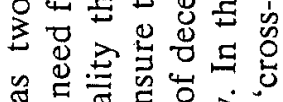

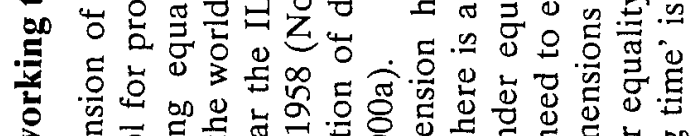

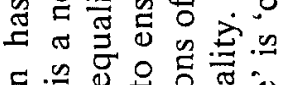

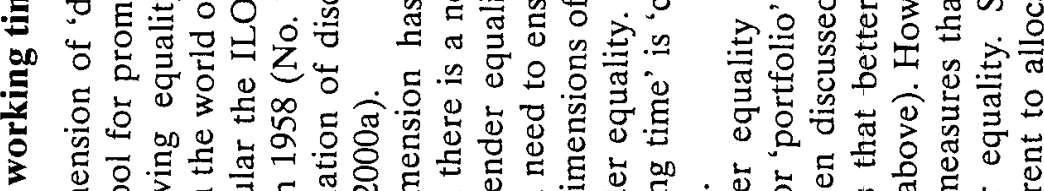

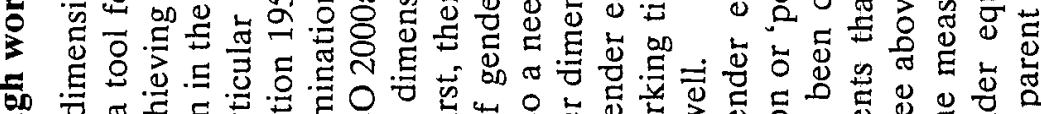
on

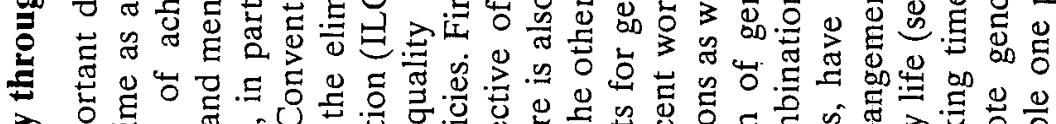

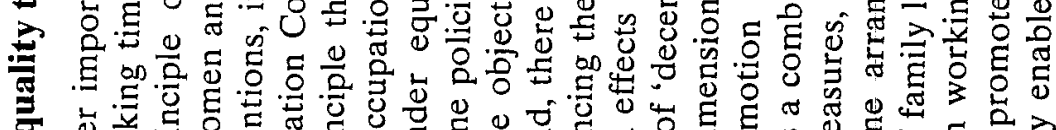

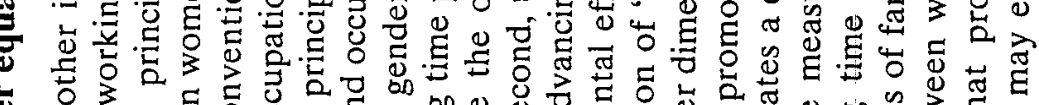

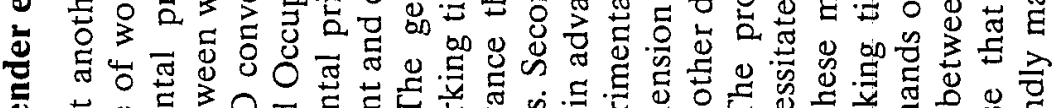

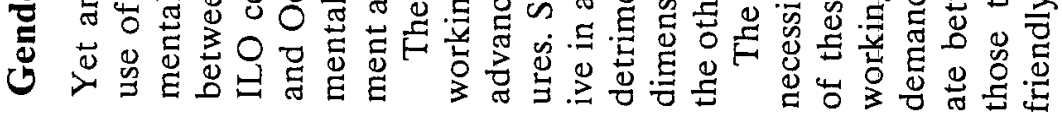




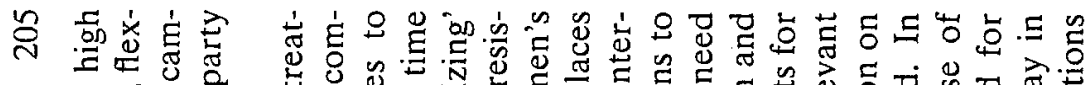
厅

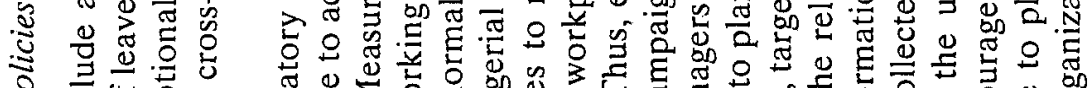

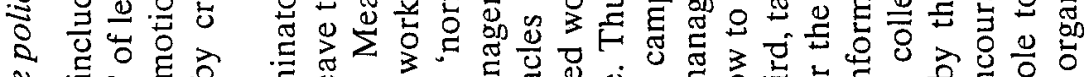

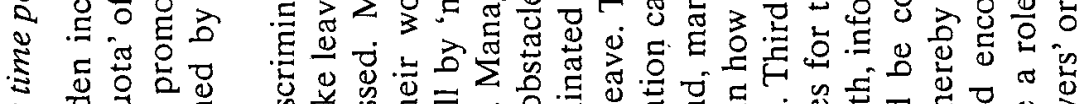

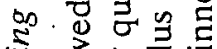

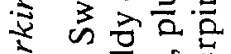
.

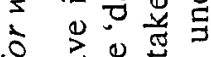
远

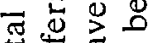

焉

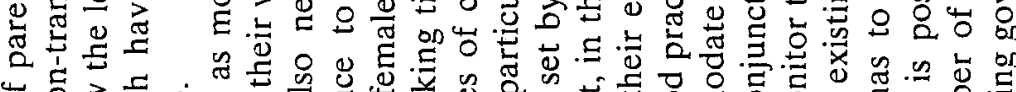

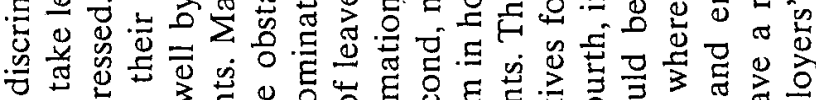
\&

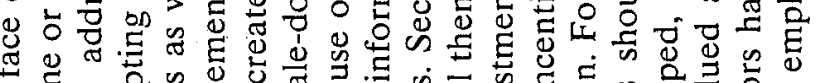
E o o o

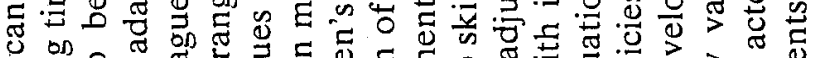

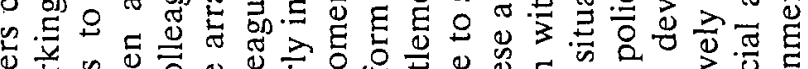

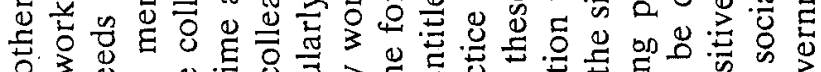
它 35

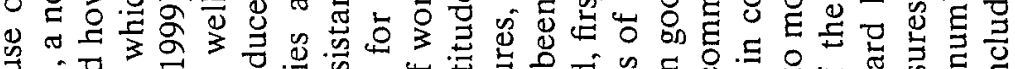

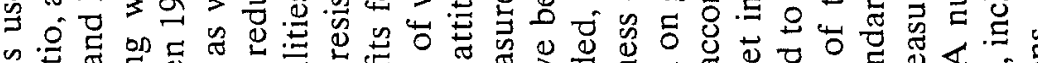

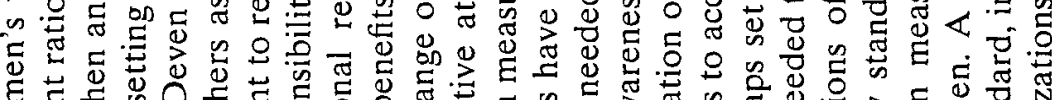

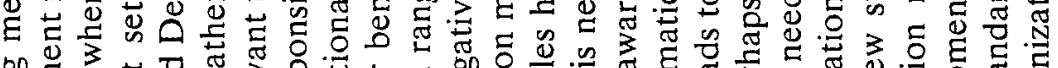
on E प

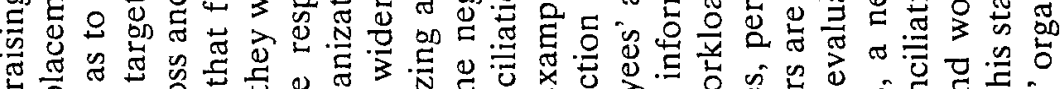

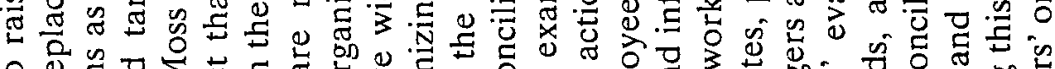

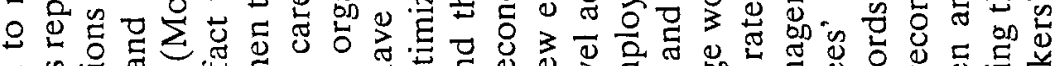

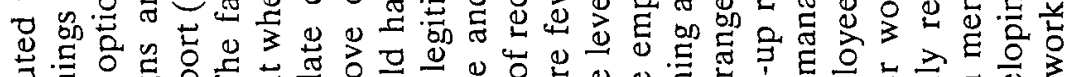

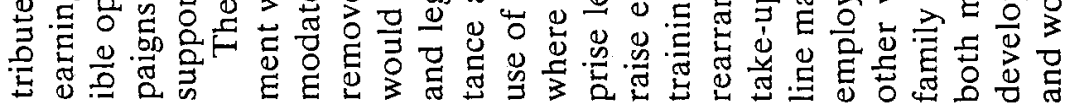

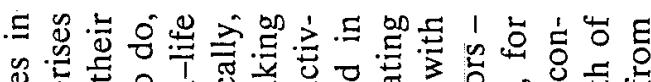
क

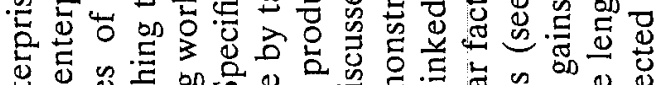

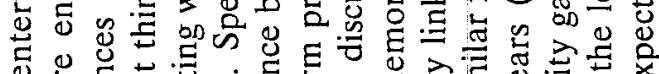

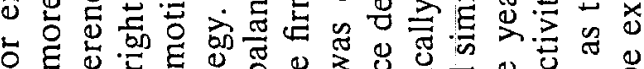

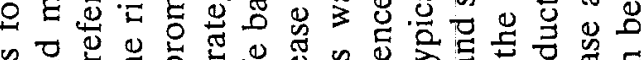

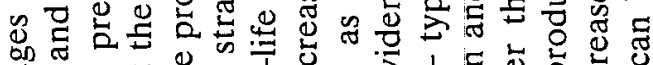

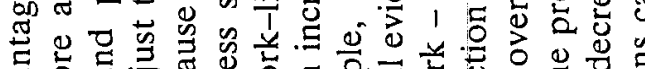

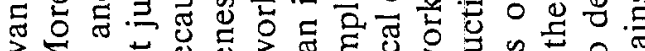

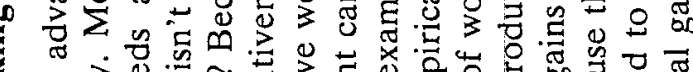

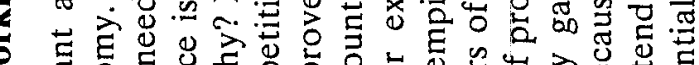

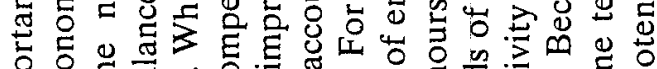

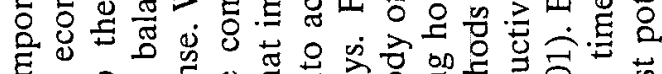

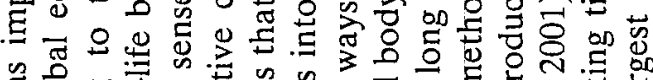

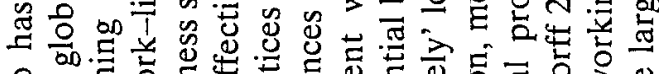

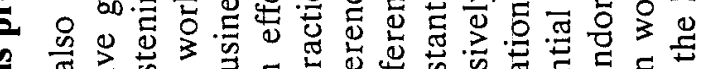
ส

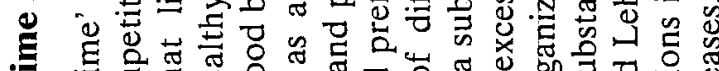

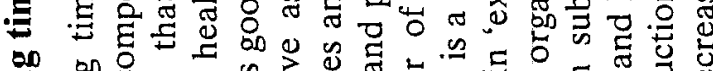

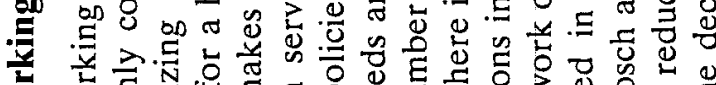

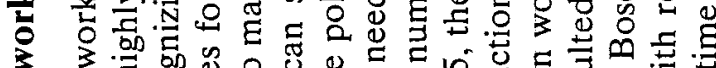

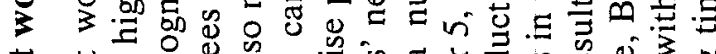

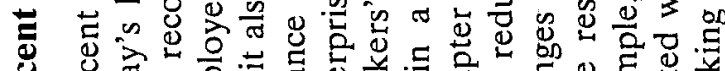

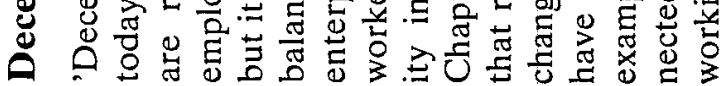

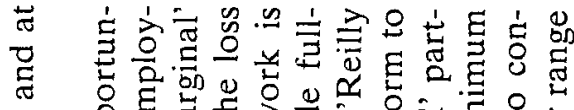
党

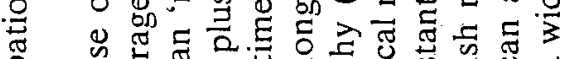

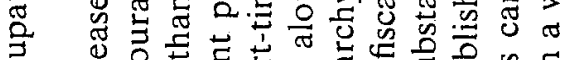

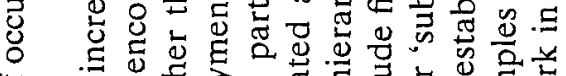

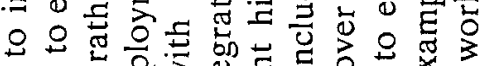

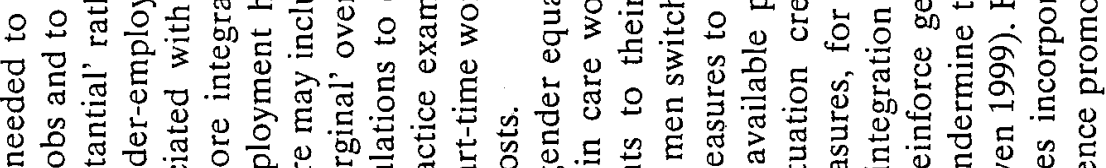

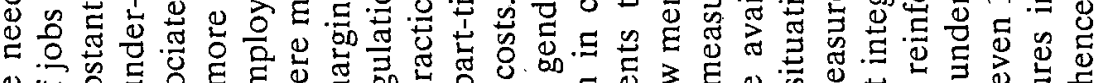

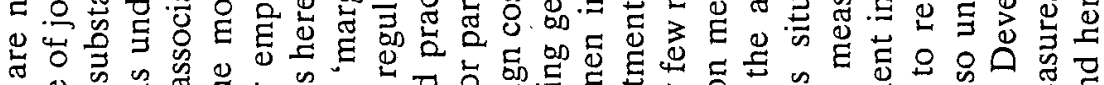

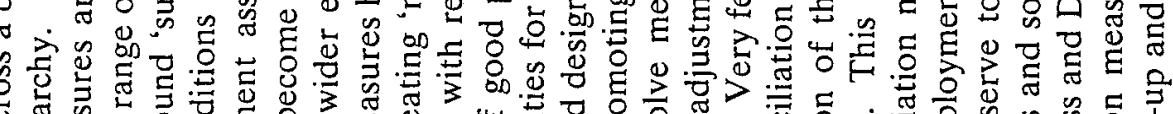

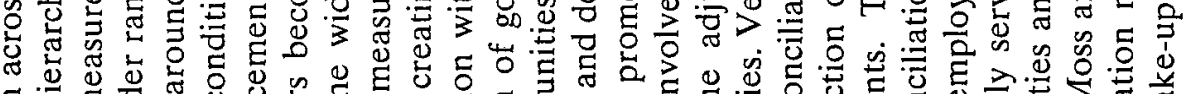
ब.

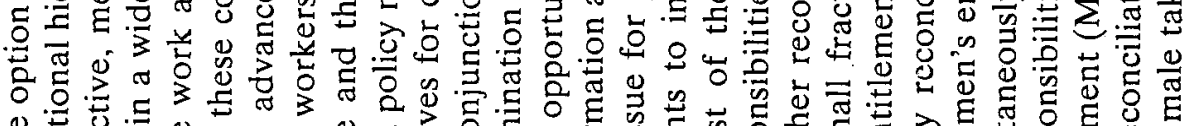

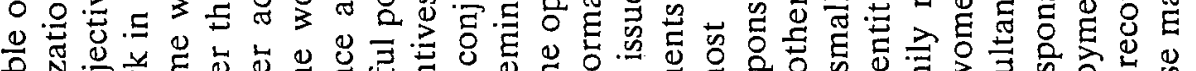

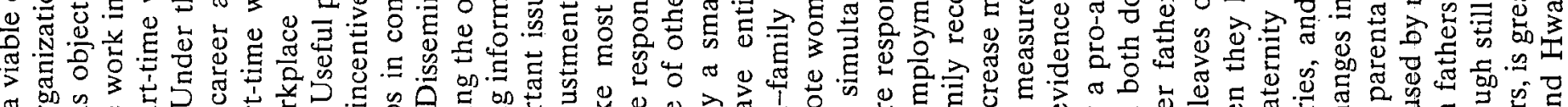
o

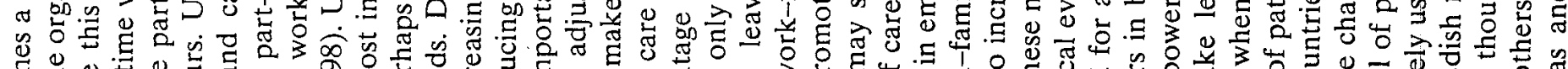

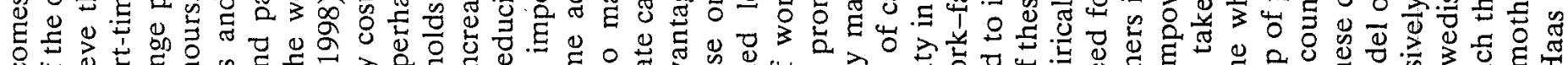

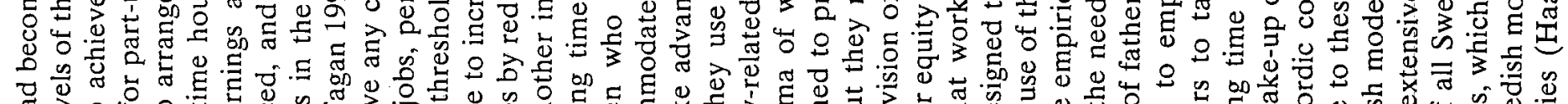

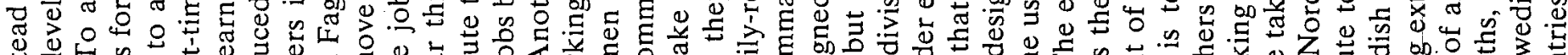

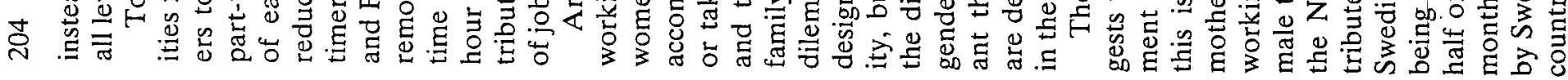




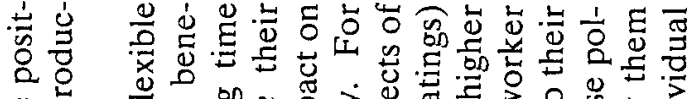
造 Ex o $\overrightarrow{0} \pi$ 可 要

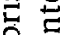

它要

党

造

䜦

¿ृ̃

若

\section{.}

过

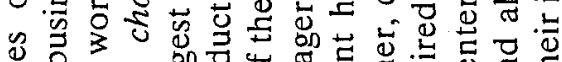

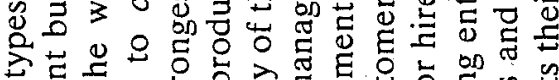

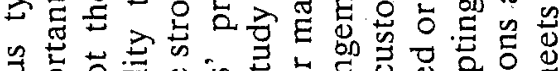

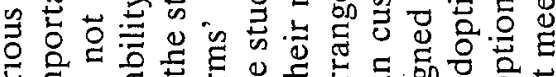

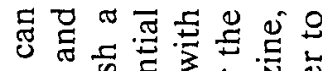
0 员 要. 西 원.

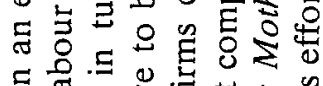
.

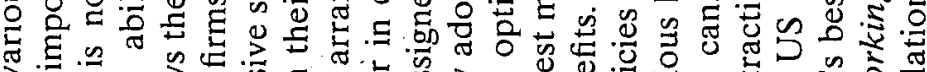
on 0 क

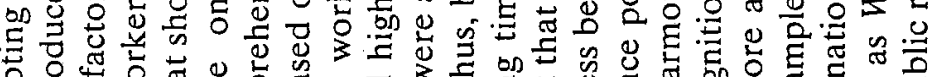

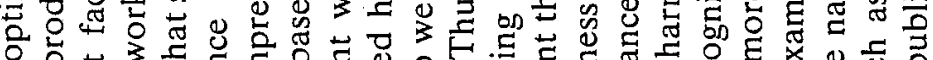
我

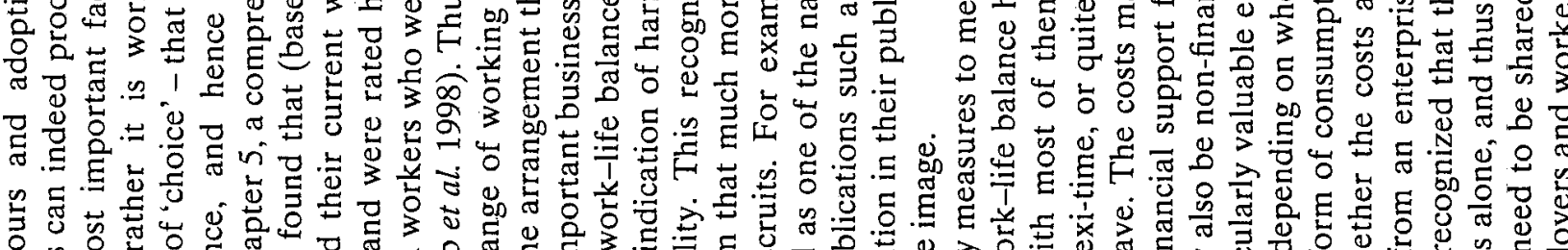

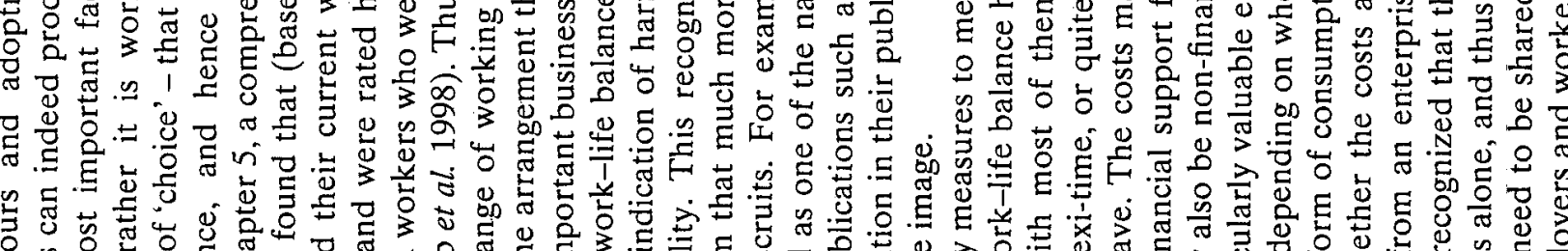

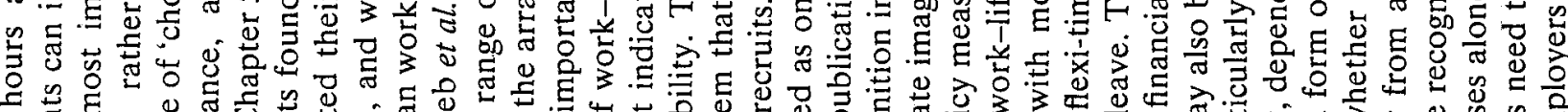

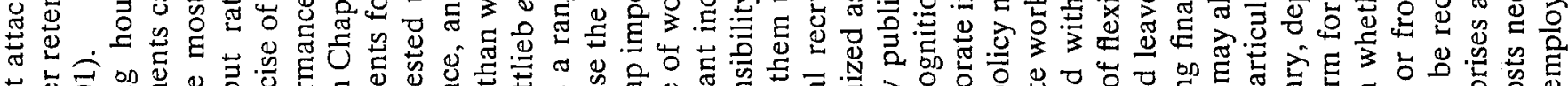

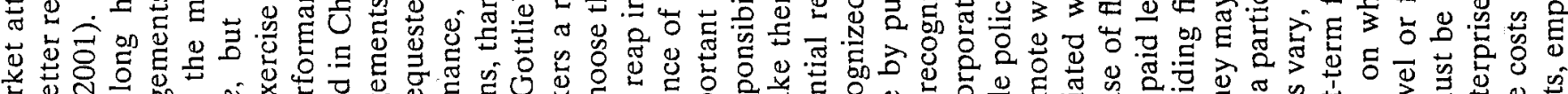

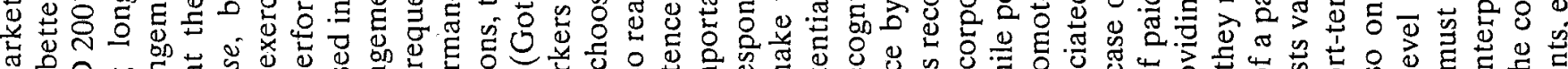

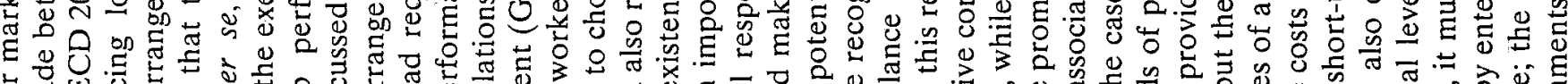

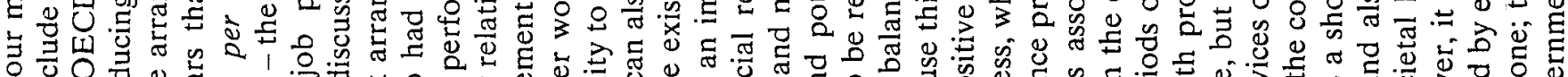

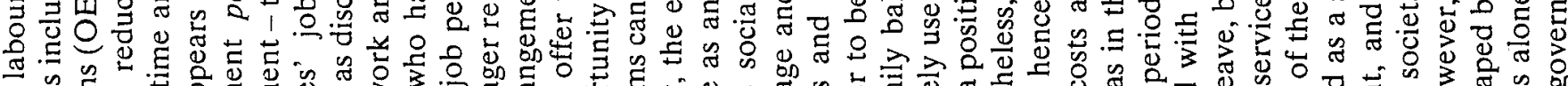

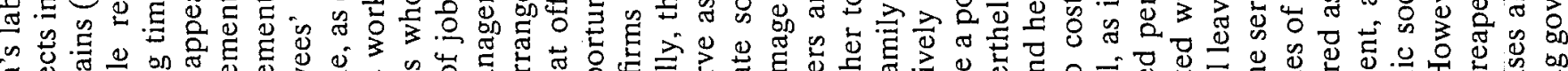

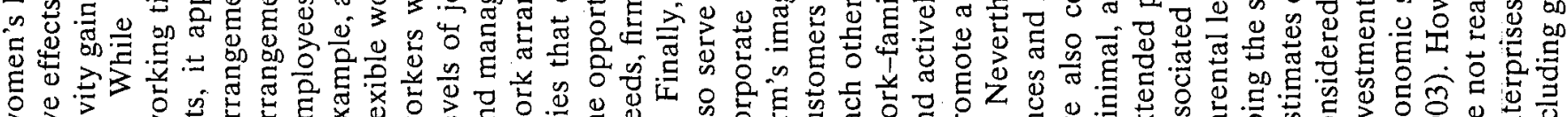

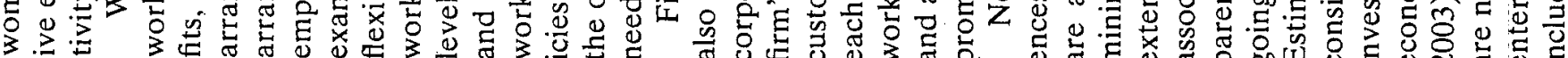

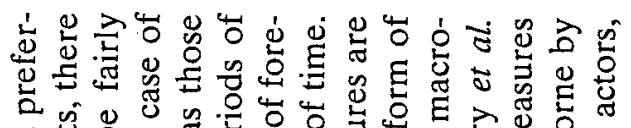

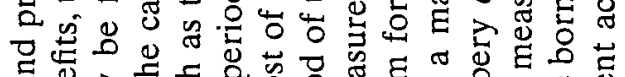

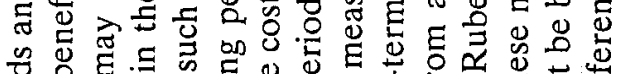

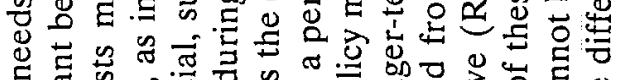

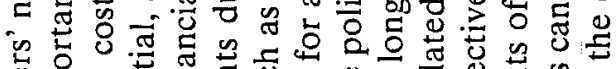

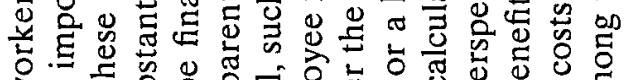

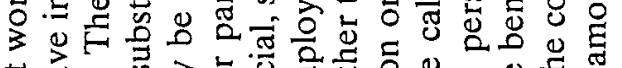

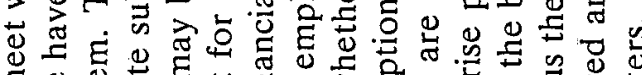

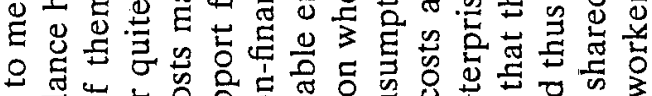
为

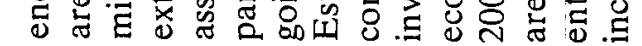

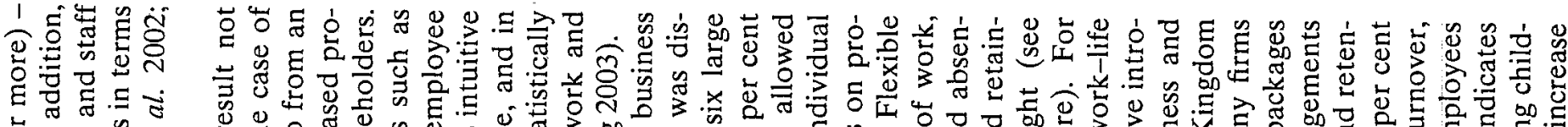

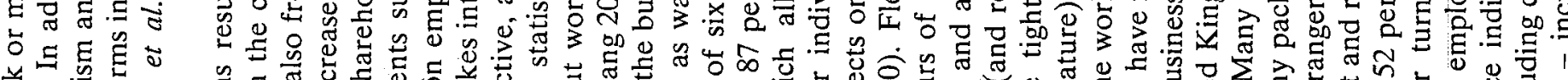
य

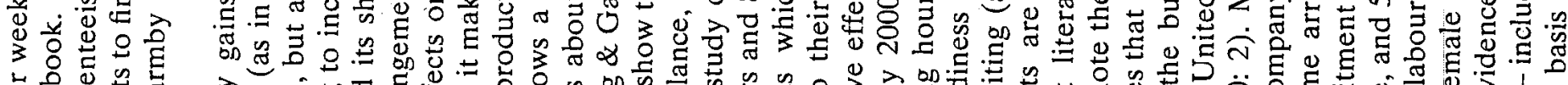

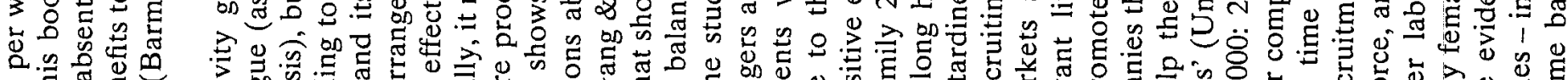

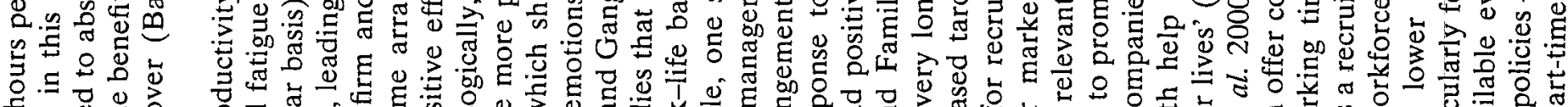

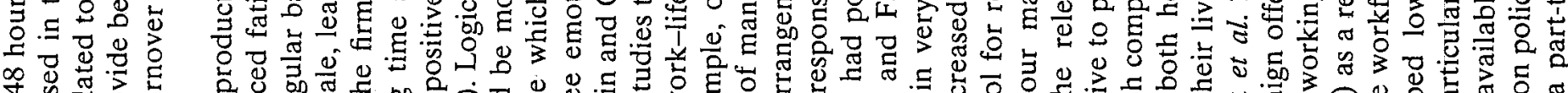

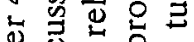

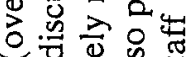

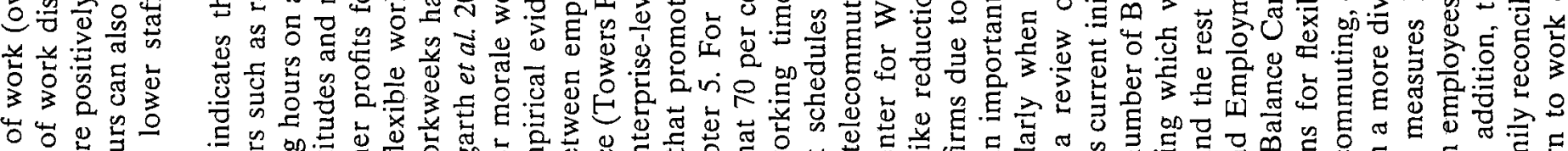

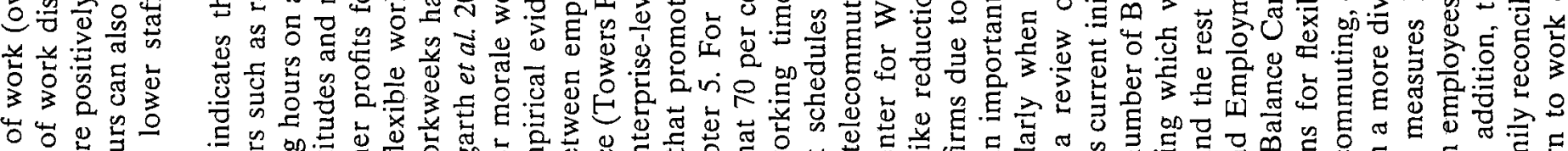

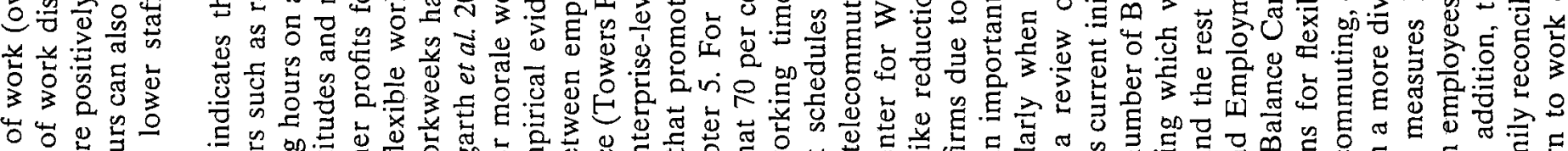

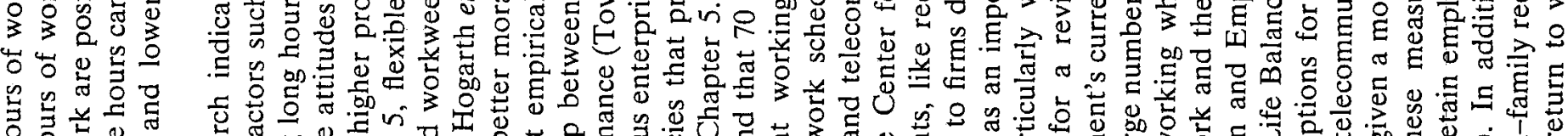

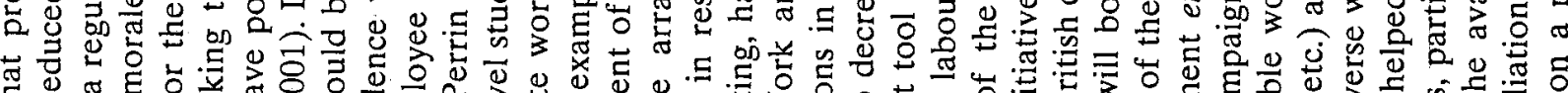

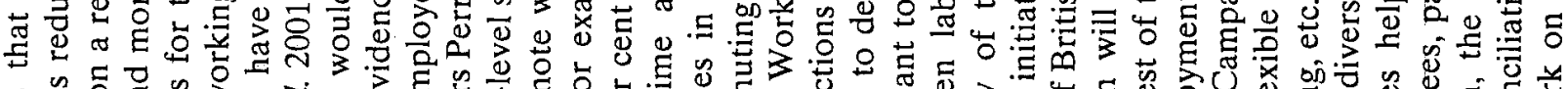

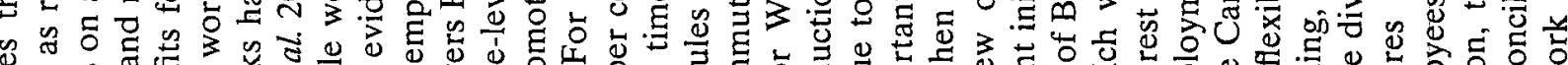

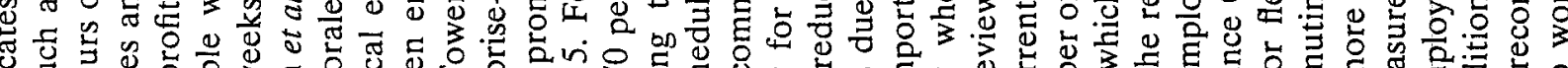

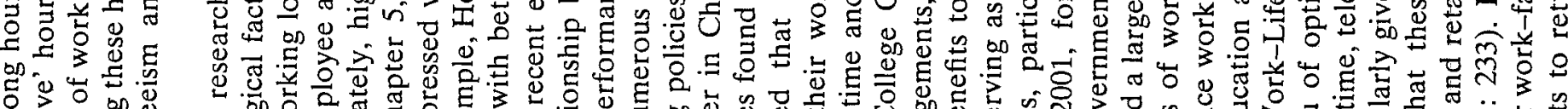

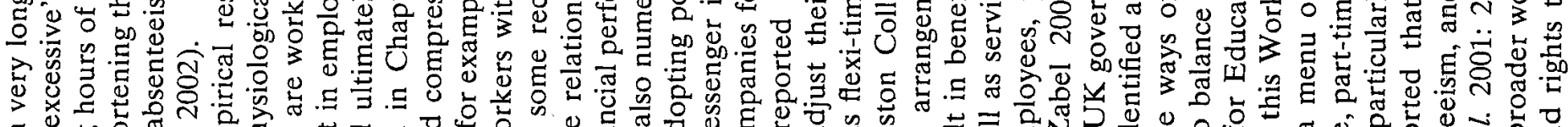

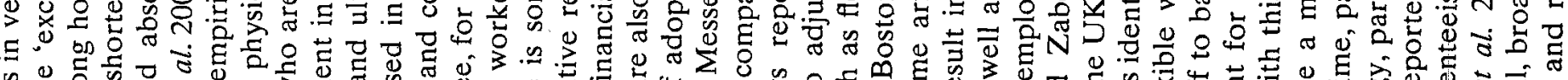

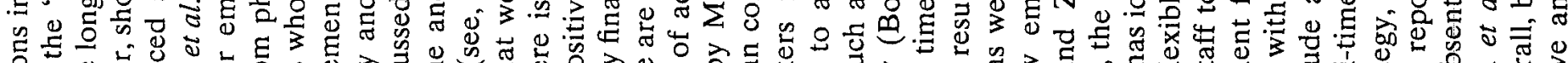

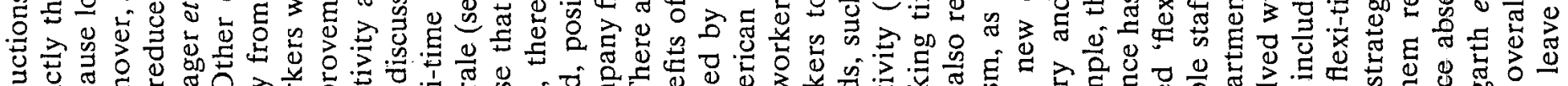

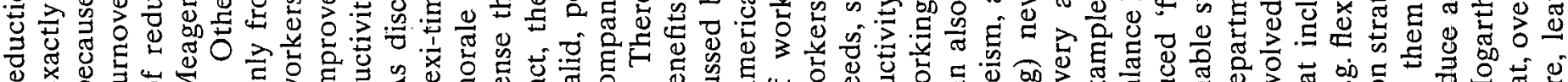

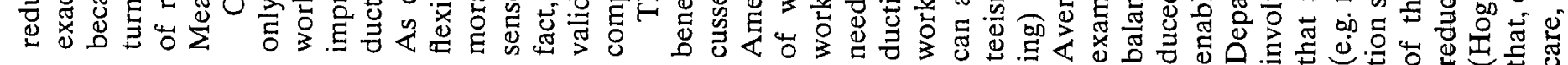




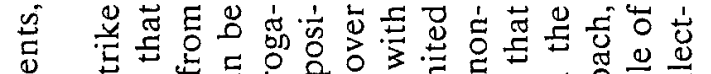

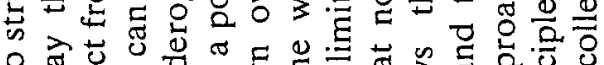

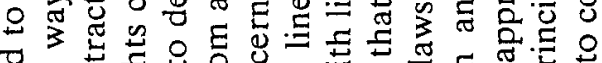

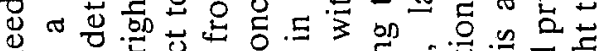

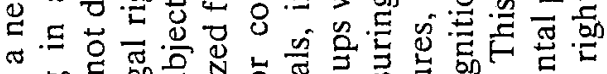

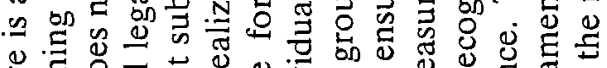

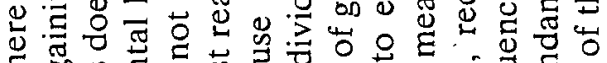
ङ

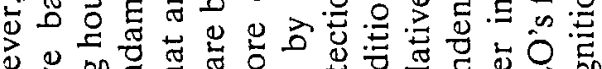
》

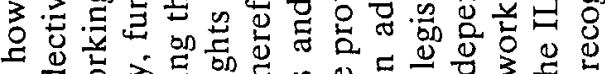

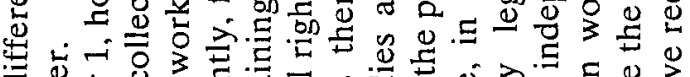

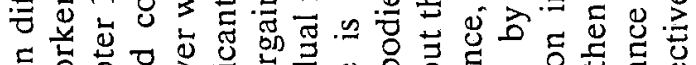

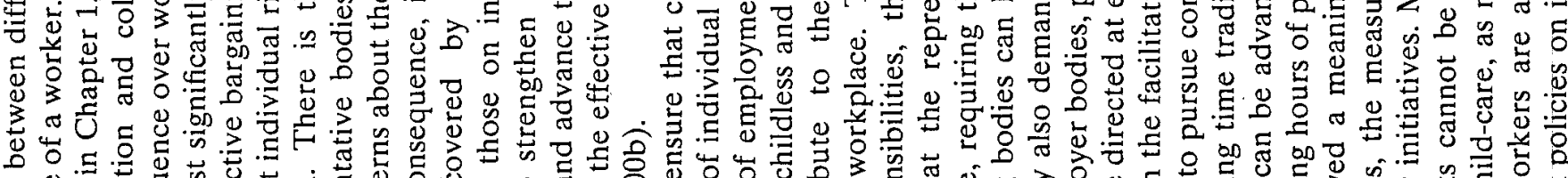

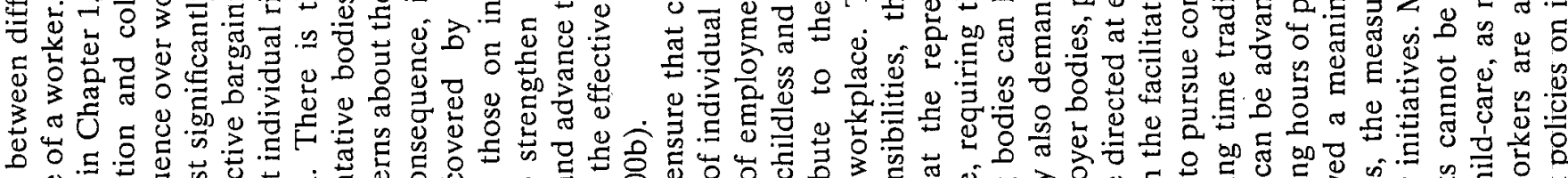

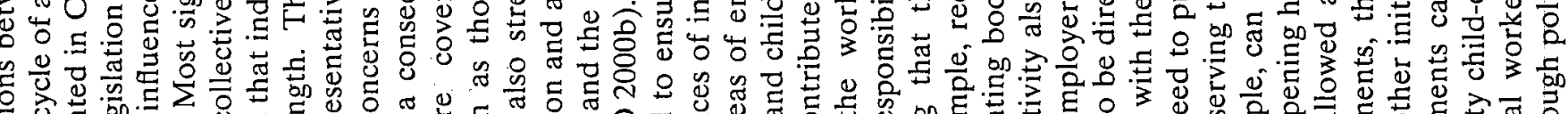

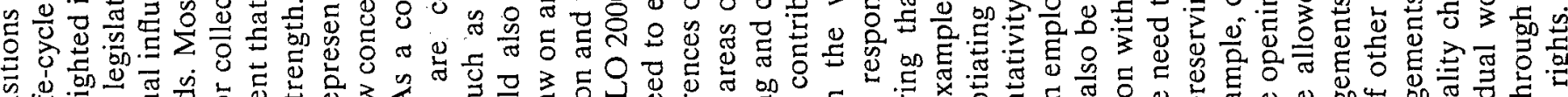

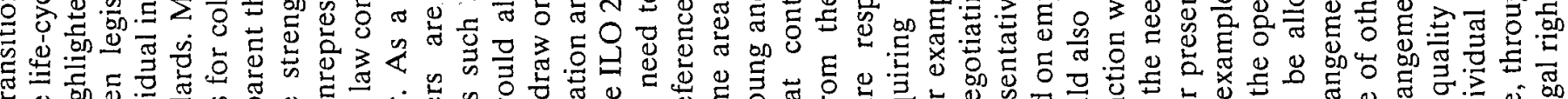

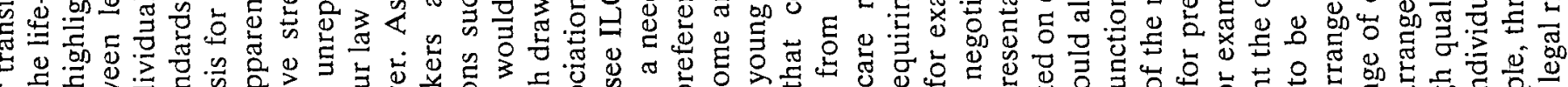

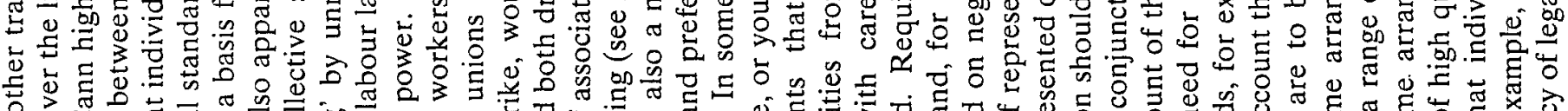

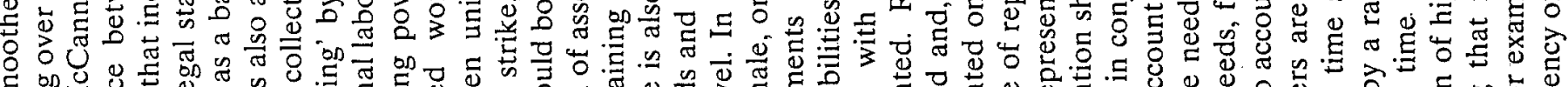

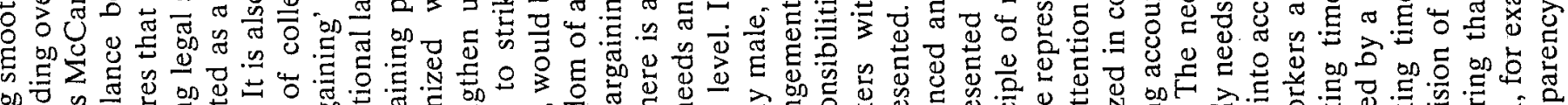

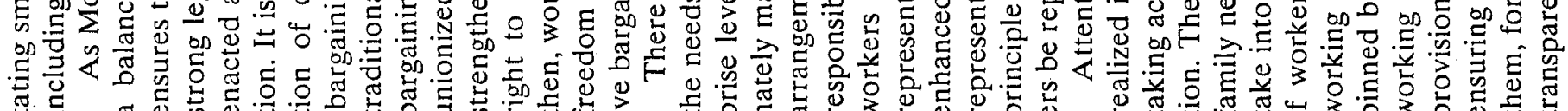

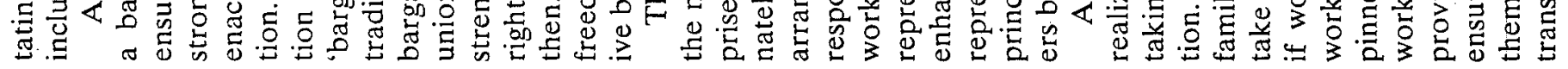

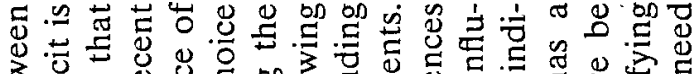

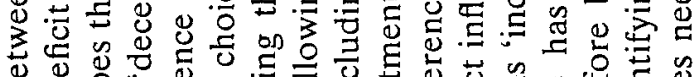

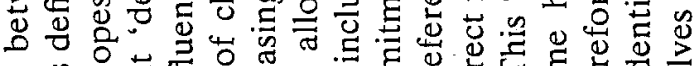

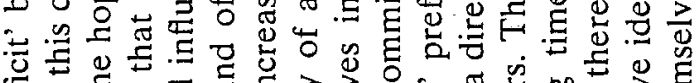

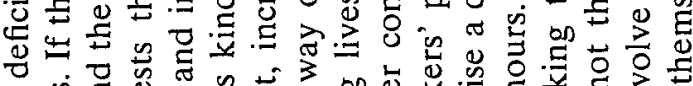

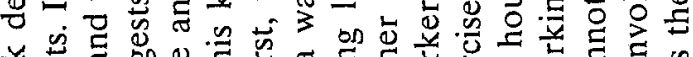

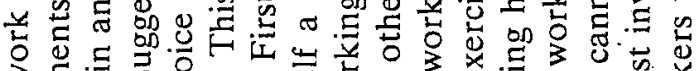

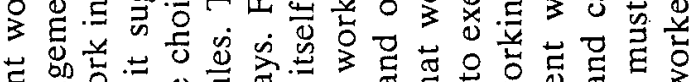

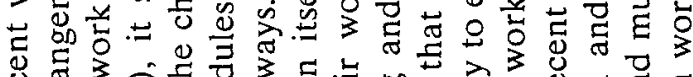

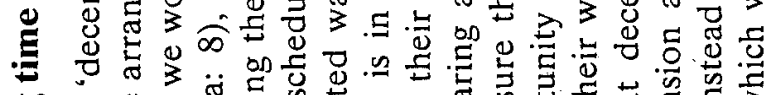

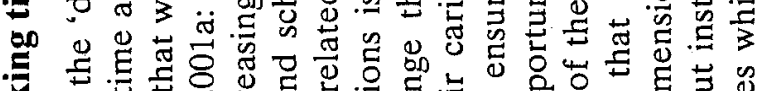
牙

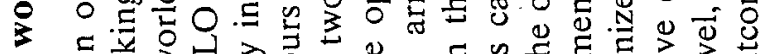

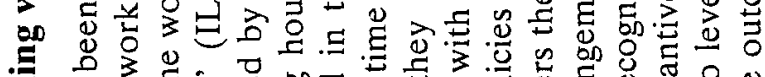
F 車

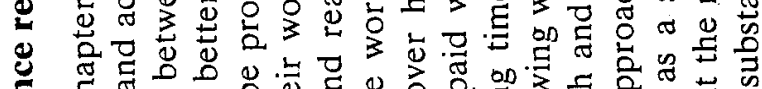

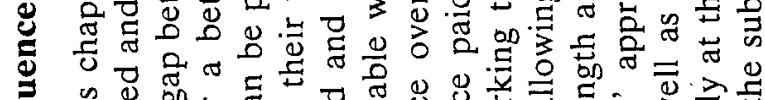

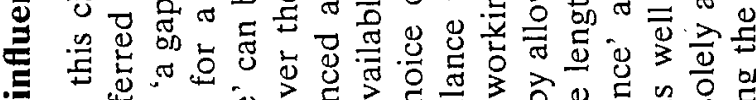

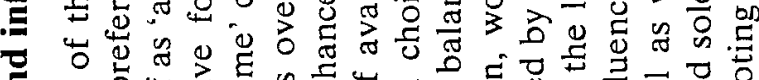

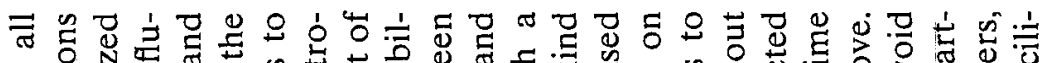

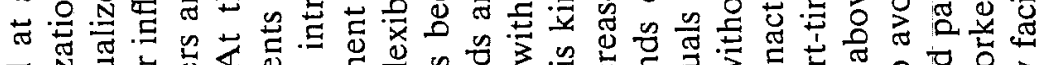

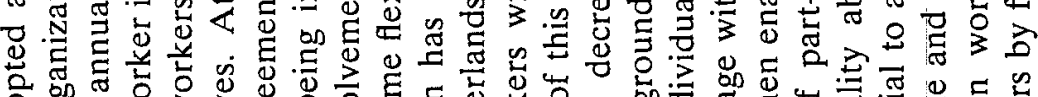

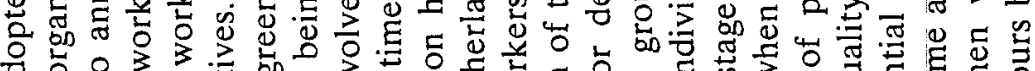

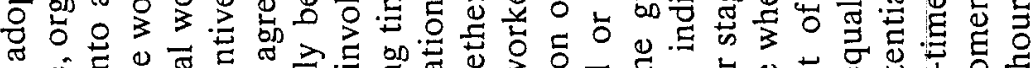
ڤ.

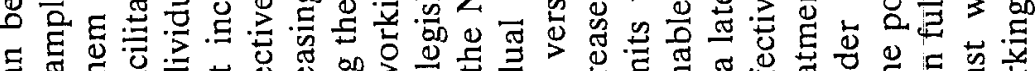

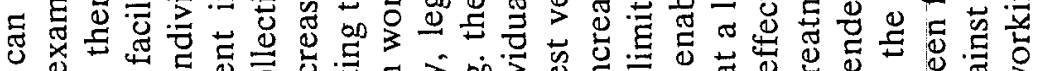

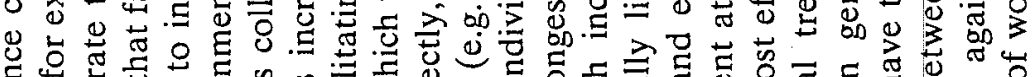

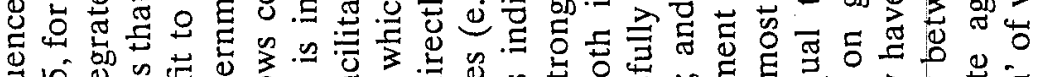

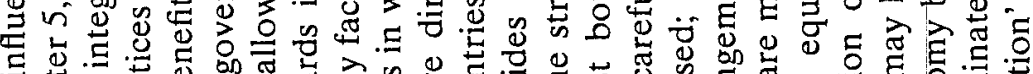

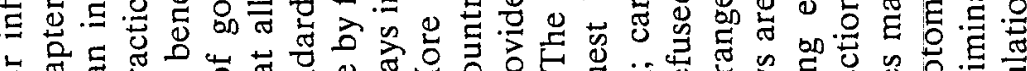

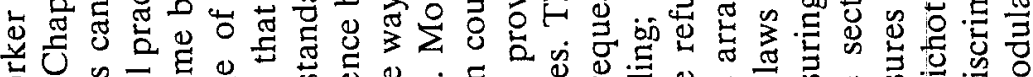

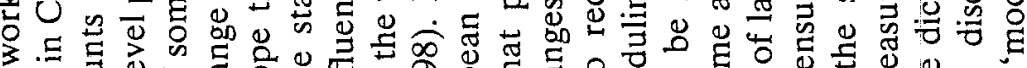
o

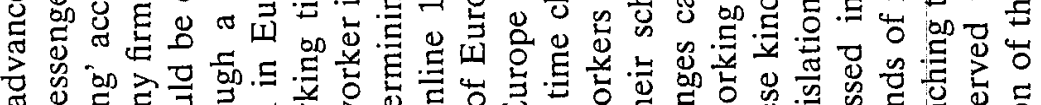

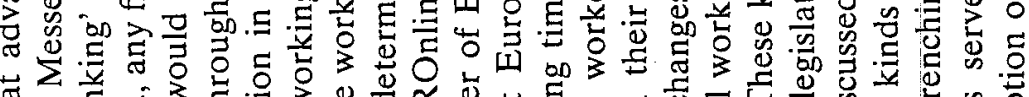

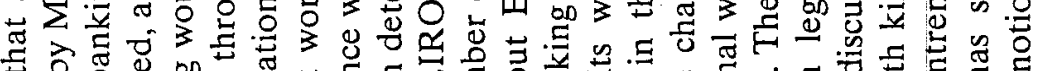

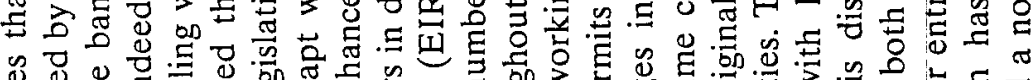

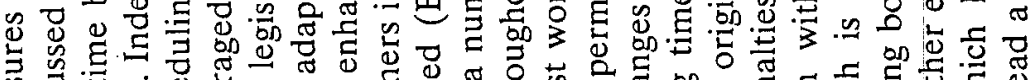

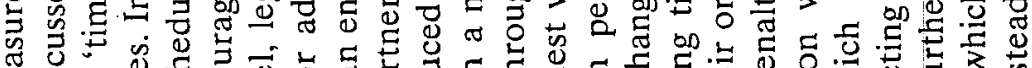
ه.

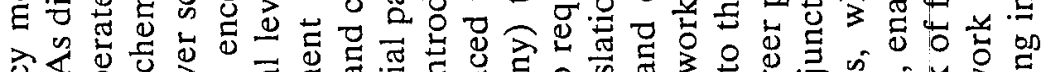

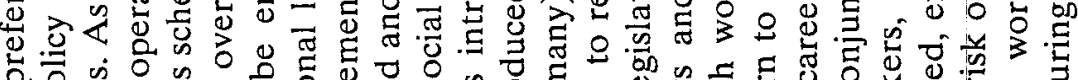

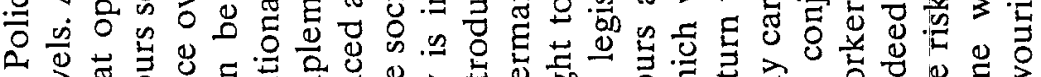

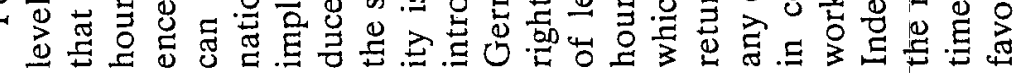




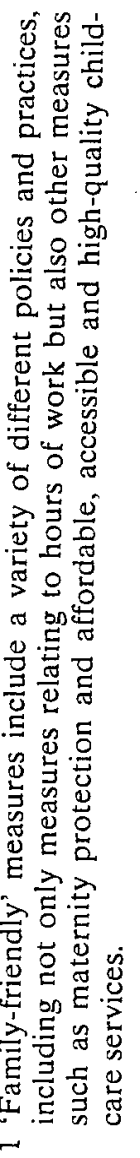

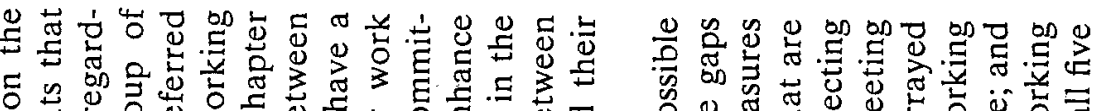

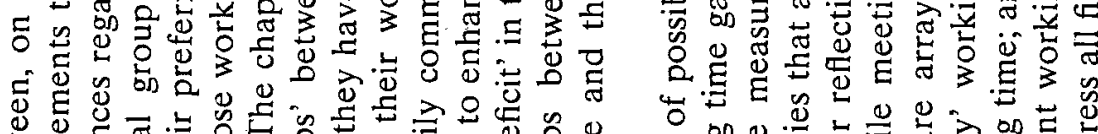
d

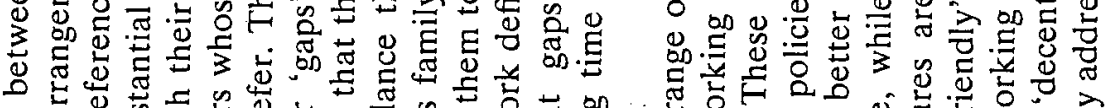

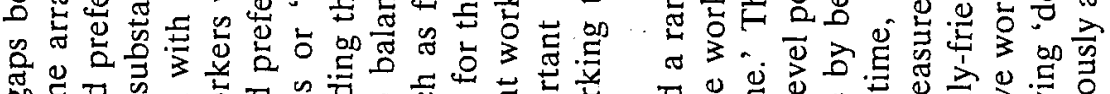

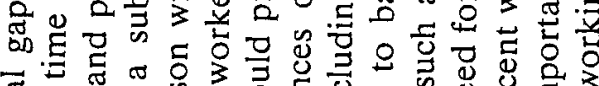

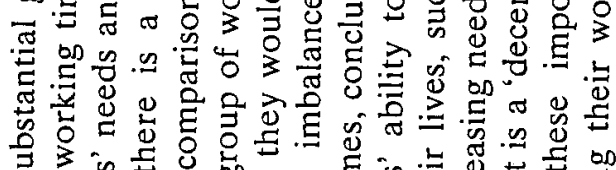

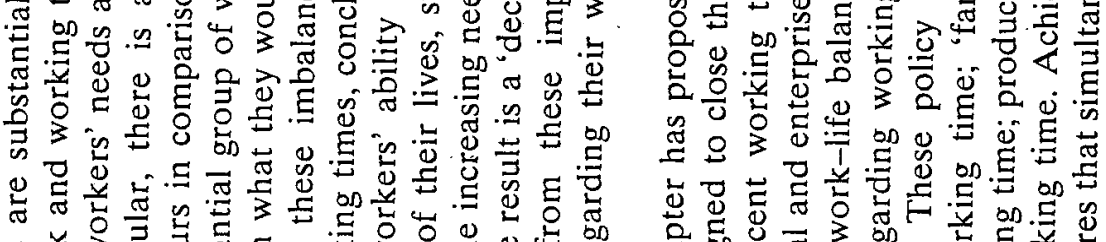
ब

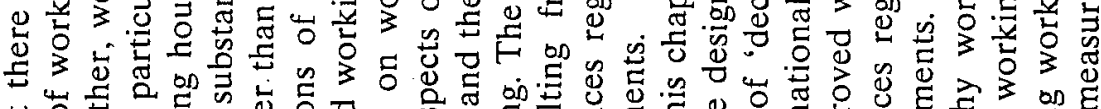

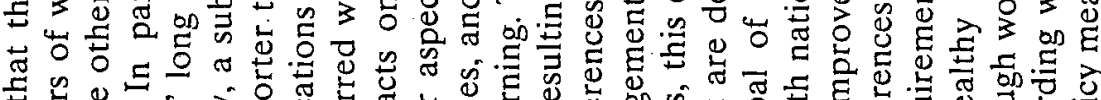

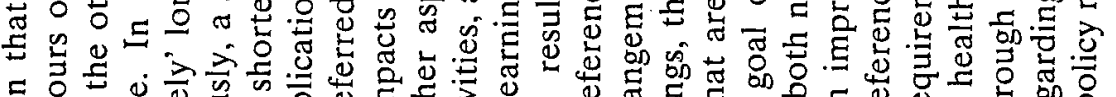

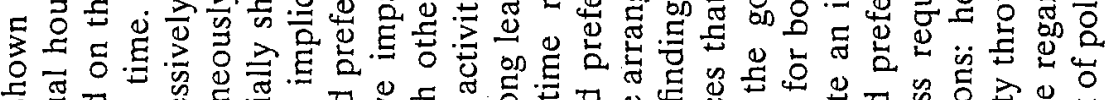

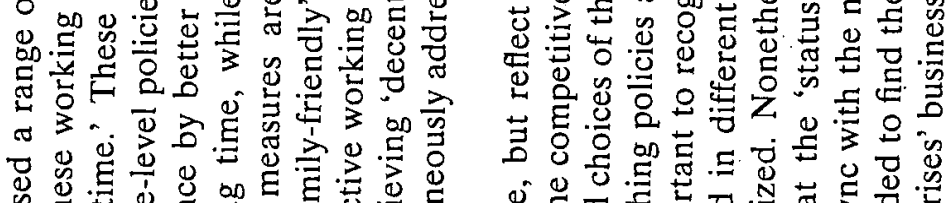

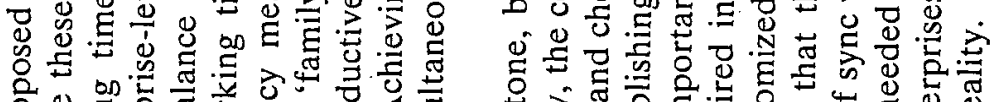

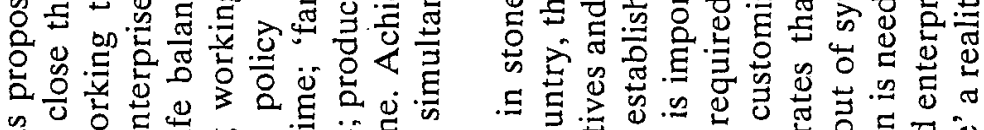

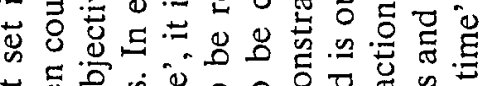

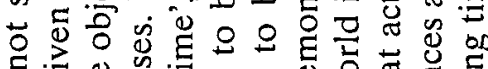

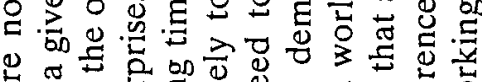

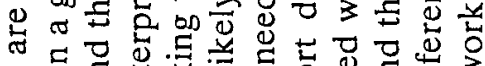

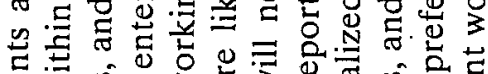

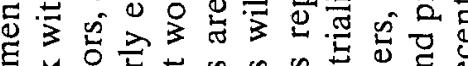

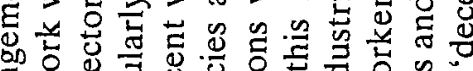

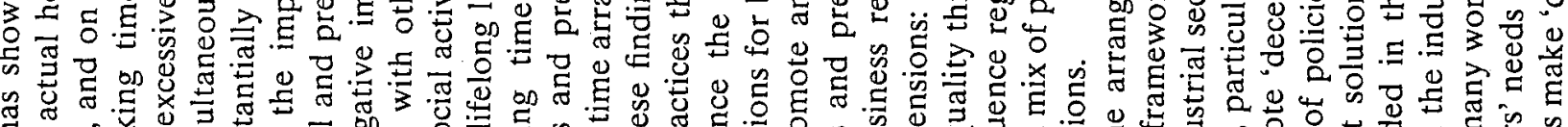

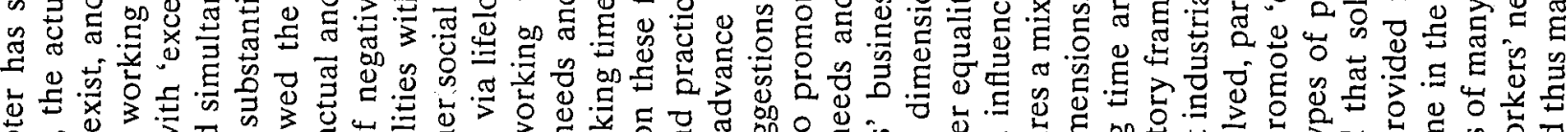

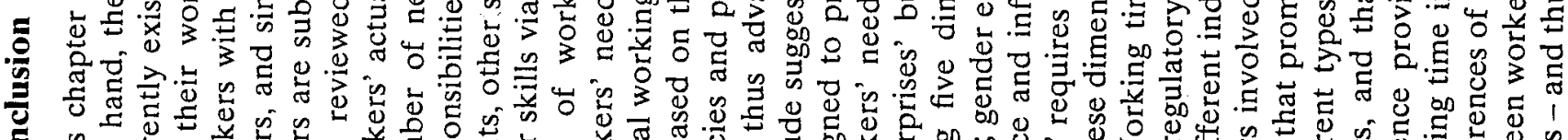

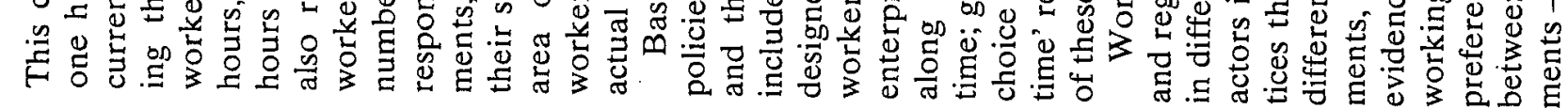

